\title{
4 Coup and Anti-Coup
}

\author{
Islamist resistance and the National Alliance in Support of \\ Legitimacy
}

\begin{abstract}
The military coup was a constitutive event. It triggered political subjectivation processes both within the Islamist camp and within the coalition of players who had asked for Mursi's deposition. This chapter shows how the coup virtually dichotomized Egypt's political arena. This new societal division cut across the formerly salient division between the people and the regime by pitting an alliance of civic and state forces against an equally variegated coalition of anti-coup forces. In this contest, both sides articulated competing conceptions of legitimacy to discredit their respective opponents and lionize their allies. They thereby unwittingly conditioned alliance-building, authorities' means of responding to protest as well as how the public would come to evaluate the contending players and their actions and goals.
\end{abstract}

Keywords: Anti-Coup, coalition building, counter-mobilization, Islamist movements, legitimacy, repression

General Abdel Fattah al-Sisi announced Mursi's arrest and the coming changes in government on July 3, 2013, at 7 p.m. local Egyptian time. His speech signaled that the army had learned from past mistakes: Rather than assuming power itself, it installed a civilian transition government. Led by Adly Mansour, a respected judge and the former head of the Supreme Constitutional Court, as interim president this government was charged with implementing a transitional roadmap. Aside from new elections and the formation of a national reconciliation commission, this roadmap included the elaboration of a new constitution, a reformation of the electoral law, and the implementation of a new ethical codex for the country's media outlets. An interim cabinet was authorized to rule by decree.

Grimm, Jannis Julien, Contested Legitimacies: Repression and Revolt in Post-Revolutionary Egypt. Amsterdam: Amsterdam University Press 2022 DOI: $10.5117 / 978946372265^{\circ}$ _CHO4 
For his televised address, Al-Sisi was joined by representatives of Egypt's religious institutions, opposition party leaders, and high-ranking officers in a carefully stage-managed visual framing process (see Abdel Ghaffar, 2013). The sheik of Al-Azhar Ahmed Al-Tayyeb and Coptic Pope Tawadros followed Al-Sisi at the podium with speeches of their own, confirming their support for the steps taken by the army. National Salvation Front leader Mohamed El-Baradei and Tamarod spokesman Mahmoud Badr spoke last. Significantly, a leading member of the Salafist Nour Party attended the announcement as well, letting the military intervention appear as a broad consensus of Egyptian society, rather than an antiIslamist coup.

Aside from creating tangible facts on the ground - such as the arrest of Egypt's first freely elected President alongside 250 mid and upper ranks of the Brotherhood and its Freedom and Justice Party (FJP) - the coup d'état had also a symbolic side. As a discursive event, it provided a constitutive myth for two opposing political projects whose competition would dominate the political arena in the years to come. The coup dichotomized Egypt's political public by delimiting the frontier between two opposing camps of players. In this struggle, both sides derived their legitimacy from competing conceptions of democracy, legality, and the country's revolutionary heritage; both sides claimed to represent the popular will and to speak for the people; and both sides engaged in vicious vilification of their respective other, depicting it "as an existential threat, yet paradoxically also as a minuscule fringe side-lined by their clear majority" (Mogahed, 2013). Most importantly, Mursi's deposition became the catalyst for the largest wave of Islamist mobilization in Egypt's republican history, and paved the way for the emergence of a complex and powerful new player in the shape of the so-called "Anti-Coup Alliance."

\section{From Government to Opposition}

The National Alliance in Support of Legitimacy (NASL) had been demonstrating in support of President Mursi since mid-June. But after July 3, 2013, this alliance transformed rapidly from an advocacy coalition in support of the incumbent Mursi government into a street movement and the central oppositional player to the consolidating post-coup regime. The coup bestowed upon the alliance a new role as the primary pressuring mechanism for a broad coalition of mostly Islamist players who rejected the military intervention as an illegitimate coup against the country's democratic transition. 
The coalition honored the president's last speech and made opposition to the coup and the restoration of shar'aiya [legitimacy] the epicenter of its campaign. As it added the suffix "in Rejection of the Coup" to its original name and called for country-wide protest marches, it soon came to be known as the Anti-Coup Alliance. The myth of a national initiative for the restoration of constitutional, democratic, and revolutionary legitimacy became the surface for the inscription of a variety of demands and meaning constructions under the umbrella of the Anti-Coup Alliance. As the central nodal signifier, this specific conception of legitimacy also defined the boundaries of the Anti-Coup movement's collective identity.

Rabaa al-Adawiya Square in the Cairene neighborhood of Nasr City became the epicenter of this movement's activities. By squatting on Rabaa Square, the Brotherhood and its allies adopted a contentious repertoire that, according to Carola Richter (2017) has become "a global signifier for staging anti-establishment protest" (p. 106). Across borders, especially major urban roundabouts have become eminent sites of confrontation between revolutionary and reactionary groups (see McCurdy et al., 2016; Weizman et al., 2015). The symbolism of these occupations, as Jonathan Liu (2011) notes, is almost jokingly obvious: "What better place to stage a revolution, after all, than one built for turning around?"

As Mona Abaza (2014) has argued, the choice of Rabaa al-Adawiya was not a "last resort" (p. 165) but deliberately contrasted with Tamarod-occupied Midan Tahrir. The latter is a site that is not only heavily loaded with revolutionary symbolism but has also served, for decades, as the site of annual parades to celebrate the 1952 military coup (Weizman et al., 2015, p. 37). If Tahrir Square provided some sort of public voice to those who supported military intervention into civilian politics, Midan Rabaa provided something of a counter-public. ${ }^{1}$ Located on a major intersection of Nasr City, the square offered several advantages: First, Nasr City is charged as a symbol of the military's embedding into Egyptian society. The urban conglomerate was planned and built in the late 1950s and early 196os under the auspices of Gamal Abdel Nasser and houses Egypt's Al-Azhar University. Next to Rabaa al-Adawiya Square is the Tomb of the Unknown Soldier on Al-Nasr Road. Across the street, facing the tomb is the Minassa [tribune] memorial for the assassination of former President Sadat. Several military clubs and the principal military parade street are close by (Abdelbaseer, 2016). The occupation of a major square in the vicinity of these sites challenged the coup leaders' interpretive authority over the role and function of the armed forces in Egyptian politics. 
In addition to Midan Rabaa, a second large camp was created on Midan Al-Nahda [Renaissance Square] in the vicinity of the Cairo University, on the other bank of the Nile. Until their dissolution by police in mid-August, these two sites in the capital geographically concentrated most of the unseated president's supporters. Moreover, the two squares served as hubs for a large portion of the demonstrations in Cairo and Giza, where different marches originated and converged. But contention did not remain limited to the capital. During the period investigated in this book, the decisive first 100 days after the coup against Mursi, I have documented 2,433 discrete protest events that can be attributed to the Anti-Coup Alliance. These events took place in all provinces, albeit with a clear focus on the governorates' capitals.

Figure 1 Trajectory of Anti-Coup protests and state repression

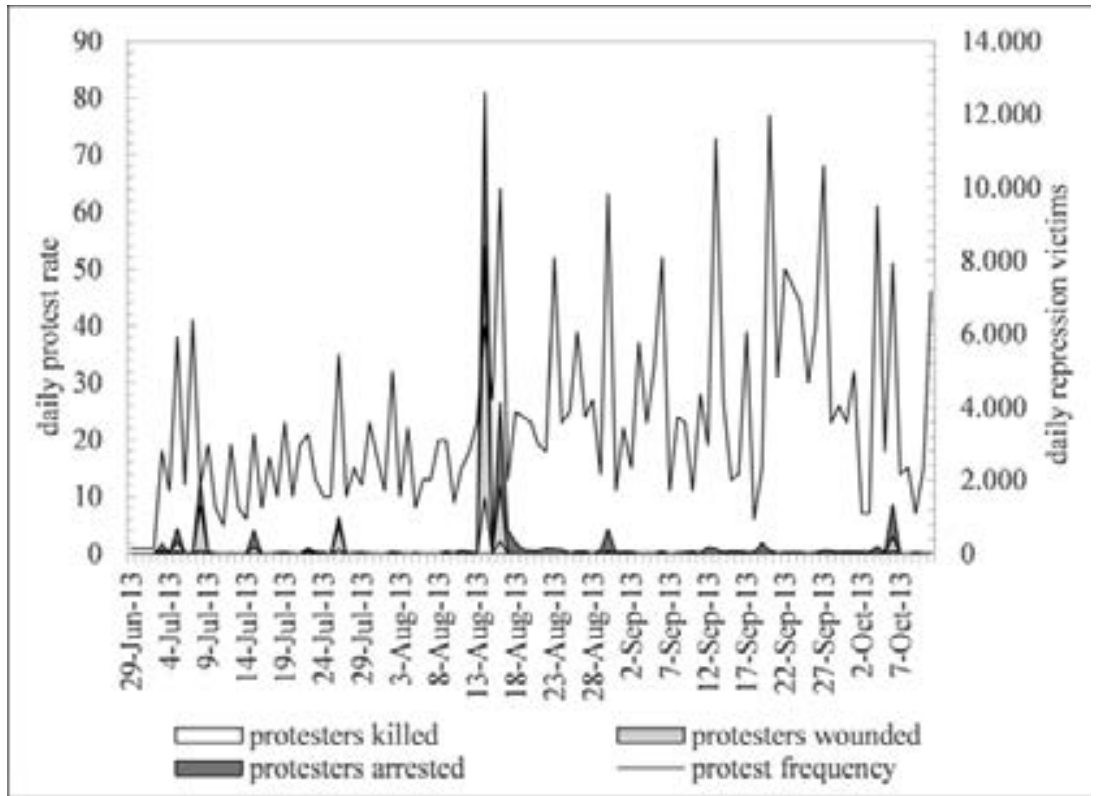

Protest events were not normally distributed across the investigation period. Several instances of condensed event data point to episodes of accelerated mobilization and an escalation of contentious interaction. These findings correlate with the available data on victims of state repression: For the investigation period, Wiki Thawra has documented the violent deaths of 2,305 and the physical injury of 11,517 people by violence from security forces including police, riot police, and army units. 14,442 people were arrested. Significantly, most peaks in the dataset correspond with those 
phases that were marked by an intensification of protest. Combined, the diagrams highlight four distinctive episodes of contentious interaction between protesters and security forces:

1 First, the deposition of Mohamed Mursi triggered an initial phase of collective action that concentrated on the surroundings of Midan Rabaa al-Adawiya, on Al-Nahda Square in Giza, and Salah Salem Street in downtown Cairo.

2 Second, the first mass killing of demonstrators in front of the Republican Guard headquarters on July 8, 2013, precipitated a cascade of regular daily marches that contributed to the institutionalization of the AntiCoup Alliance as a coherent player.

3 Third, the public call by then-Defense Minister Al-Sisi for a popular mandate to confront terrorism, followed by a mass protest on July 26 , 2013, marked a turning point for the regime's dealing with the protest and resulted in the deadly clashes on Nasr Street.

4 Finally, fourth, the simultaneous raids of the camps on the Rabaa and Al-Nahda Squares on August 14, 2013, became the constitutive event for an authoritarian regression in the coat of nationalism. But they also strengthened the resolve of the Anti-Coup protesters who continued to protest in the face of death, albeit in smaller frequency and numbers.

These episodes were all defined by a precipitating event that included a massive deployment of indiscriminate and lethal state violence against protesters. These instances became "turning point events" (Pearlman, 2018) for the trajectory of the Anti-Coup movement and were usually followed by an immediate escalation of protest activities.

Significantly, aside from altering conditions on the ground, these events were also important as discursive events and became resources for identity formation. More than just reference points for collective action frames, they entered the cultural stock of the Anti-Coup movement as nodal signifiers. Thereby they were able to usher a new understanding of political reality and its possibilities (see Schwedler, 2016), exerting a precipitating effect on the Anti-Coup campaign. At the same time, the competing narratives promoted by the contending players about the events constituted the conditions of possibility for these players' actions, that is, for subsequent protest performances and repressive responses.

Especially the battle over the definition of legitimacy in the context of a democratic transition laid path dependencies for how players responded to each other's demands and actions early on. References to his constitutional legitimacy had been a constant feature of the former president's discourse. At the same time, the meaning of this nodal signifier had been undermined 
time and again by Mursi's actions. This made it a delicate topic around which to mobilize. By the time the Anti-Coup movement took to the streets, "legitimacy" had become a hollow shell - an empty signifier that was filled with different meanings by opposing camps.

\section{The Constitution of the Anti-Coup Alliance as a Political Player}

Mursi's rule had revealed the contingency of the Brotherhood's conception of democratic legitimacy. It had also paved the way for a hegemonic struggle, in which both Tamarod and the Brotherhood aimed to conclusively determine the meaning of the floating signifiers of legitimacy, democracy, revolution, and popular sovereignty. By mid-2013, this struggle had resulted in a stalemate with no faction able to expand its reading of the world into a broader social imaginary. The coup broke this stalemate and reshuffled the cards. For the Anti-Coup Alliance, it provided a founding myth that enabled alternative possibilities of collective identification vis-à-vis an antagonist other.

This is illustrated by the body of statements issued by the National Alliance in Support of Legitimacy and Rejection of the Coup (NASL) after the military intervention on July 3 which split the political arena into two opposing camps. The manner in which these statements were created reflected in many ways the consensus establishing procedures within the NASL. ${ }^{2}$ Typically, a skilled editor drafted these releases by picking up the cues from the last agreed-on and uncontested Anti-Coup statement. New events were placed in relation to these cues. Selected individuals from the NASL leadership then reviewed the resulting statement before publication. Once released, the statements expressed the alliance's common denominator, including who was to be considered an insider and who an outsider, who a potential ally, and who a coupist and thus an irrevocable enemy.

Unsurprisingly, this discourse juxtaposed the protagonists of the coup and its victims as nodal signifiers. As Helen Underhill (2016) stressed, this binary became a core element of the NASL narrative which aimed to depict the June 30 uprising and its aftermath as "a rupture in the revolution, the antithesis of democracy" (p. 53). By framing the events of July 3 not only as a coup against Mursi but as one against popular will, a frontier was constructed between the people who had been deprived of their legitimate electoral choice and the coupists who had illegitimately deposed the people's 
Figure 2 Antagonist frontier in the Anti-Coup discourse

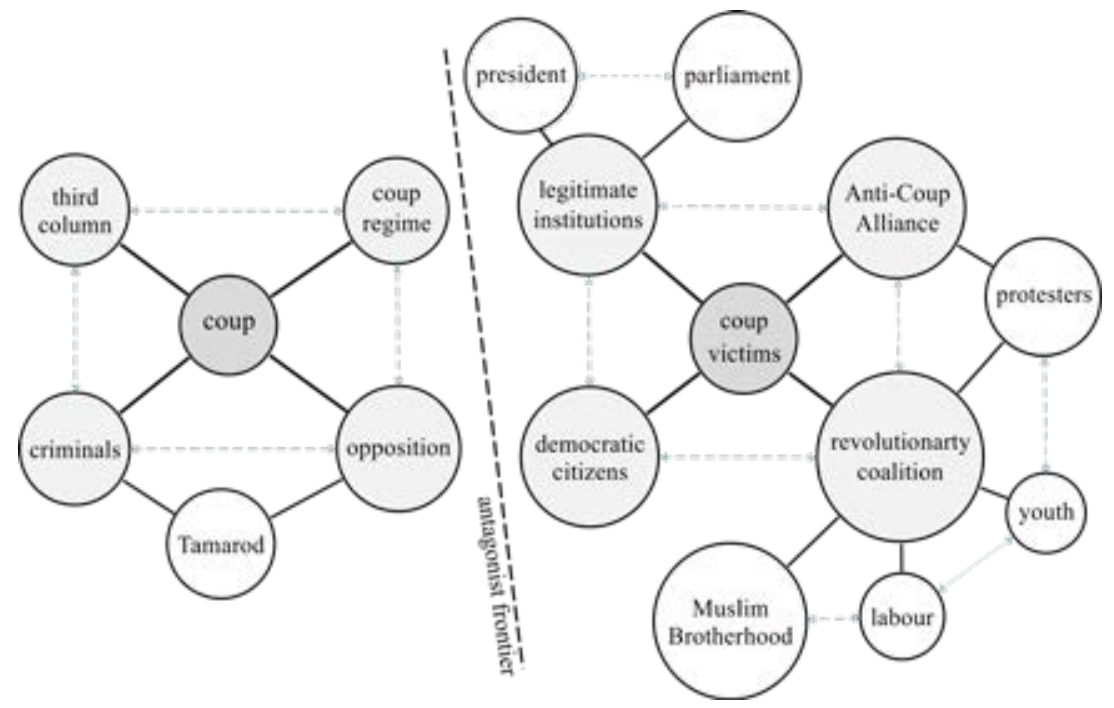

representative. The semantic network in Figure 2 illustrates this symmetric structuration of the Anti-Coup discourse. ${ }^{3}$ Therein, the coup and its victims are depicted as the nodal points for two opposing chains of equivalence that connect different clusters of discourse elements and delimited those players who were to be considered part of the Anti-Coup coalition and their actions from its opponents.

This dividing line served as a reference for juxtaposing a range of players in a differential relation: The coup leaders were constructed as the antagonist to the elected President Mursi the country's democratic leader. In a similar vein, the institutions that had backed Mursi's ouster, such as the Ministry of Interior or the domestic security apparatus, found their differential counterpart in those institutions that had supported his presidency. Those players from the ranks of the former political opposition who had welcomed Mursi's removal, in turn, were juxtaposed to the democratic citizens who shared the principles and goals of the Anti-Coup campaign. Those who had shown their support for the military intervention through street protest, including the Tamarod campaign, were portrayed as nothing more than a bunch of criminals who had been instrumentalized by the so-called third

3 In this and the following figures, a dashed line demarks the antagonist frontier separating different camps of players; dotted lines with arrowheads illustrate differential relations; these differences are dissolved by mutual relations of equivalence (simple lines) to a nodal signifier. 
column - an ostensive conspiracy of the deep state, remnants of the old Mubarak regime, and foreign powers aiming to destabilize the country (see Gribbon \& Hawas, 2012, p. 122). They were contrasted with labor and youth movements as well as Islamist groups who had made possible the January 25 uprising, in the first place.

\section{Articulating a Collective Identity}

In their exploration of the techniques by which social players, collectives or individuals, identify social problems, and reconstruct political allegiance, Jasper, Young, and Zuern (2020) emphasize the character work that goes into the articulation of social identities: "Politics is about the pursuit of power," they argue, "but one central way to get power is to persuade others that you are competent, courageous, and benevolent while your opponents are none of these" (p. 2). When it comes to compound players facing oppression and injustice, the articulation of victimhood takes an essential role in this process. It usually precedes the diagnosis of an antagonist other who is made responsible for the injustice, and the hero whose duty it is to seek a redress of grievances: "If character work can establish that there is a victim, then there must be a wrong to be righted" (Jasper et al., 2020, p. 195).

Realizing that President Mursi's earlier attempt to fraternize with the Egyptian public and present himself as a people's man had failed, the AntiCoup coalition refrained from establishing a direct link between the people and the deposed president but, instead, constructed a relation of equivalence between both only via their common victimization by the coup. Individual players' demands without necessary prior relations were thereby grouped into a popular demand for the abolition of the coup. This shared linkage as victims reproduced a common trait of political meaning work for the purpose of social mobilization.

To lend credibility to this self-characterization, the protest coalition also worked hard to alter the image of the Anti-Coup campaign as an extended arm of the Brotherhood. Albeit present on the Rabaa al-Adawiya podium and at street rallies, the NASL's official communication largely evaded any religious symbolism. Samuli Schielke (2017) claimed that Mursi's supporters, in their attempt to discredit their political rivals, produced a strongly sectarian narrative about their opponents as "Christians, godless liberals, or corrupt old regime elites - thus, once again, not the true Muslim Egyptian people" (p. 209). But this narrative was mainly produced by agitated speakers on the Rabaa stage. 
When it came to its official communication, neither the Anti-Coup Alliance's nor the Brotherhood's statements after July 3 exhibited a strong sectarian - or even religious - language. Albeit derived from the same Arabic root, the Anti-Coup discourse centered not on sharia, the religious law derived from the precepts of Islamic scripture, but on Mursi's shar'iya, his worldly legitimacy, and the legality of his actions. There was a conspicuous absence of typical Brotherhood tropes, such as the traditional slogan "Islam is the solution" (Imad, 2014, p. 239). While the coup forces were likened to the feloul, the remnants of the old regime, neither their confession nor their piety played a central role. This can be understood as a strategy to leave the movement permeable to outside support by non-Islamist political groups. During Mursi's presidency, opposition parties had regularly accused the Brotherhood of abusing religion for political gains. Well aware of their image as tujjar ad-din [religion brokers] (Monier \& Ranko, 2013, p. 116), the NASL thus adopted broader references to democratic legitimacy, in an effort to dissolve pre-existing antagonisms and bridge social polarization.

The notions of democratic citizenship and faithfulness to the goals of the revolution became key in the Anti-Coup campaign's attempts at coalition building and at linking its struggle to broader struggles against authoritarianism. The military coup, an NASL statement on July 4, 2013, stressed, had been one against "the legitimacy derived from the will of the people and revolution of January 25" (NASL, 2013d). This legitimacy had been granted via elections and referenda - democratic procedures that had been established as a result of the joint revolutionary protests of youth, workers, and Islamists. In this logic, all those players who either supported democratic due process or those who had shared the goals of the glorious revolution of January 25 were bound together through their victimization by the coup. In this perspective, solidarity with Mohamed Mursi, as the prime victim of the coup also became a matter of principle for the Anti-Coup coalition, as their communiqués illustrate (e.g., NASL, 2013g).

In essence, the Anti-Coup Alliance conceived legitimacy as based on four pillars: national security, revolutionary glory, electoral democracy, and constitutionality (see Figure 3). These four pillars defined the movement leaders' views of how to legitimately respond to the coup, and it conditioned their instructions to their followers regarding the desired repertoire of action and demands to be voiced at protest marches. From the primacy of restoring constitutionality derived the demand for restitution of the elected president, the reinstatement of the disbanded parliament, and the restoration of the rule of law. From the claim to defending the popular will derived the appeal to break the coup and protect Egypt's transition. From 
Figure 3 Construction of legitimacy and corresponding Anti-Coup action strategy

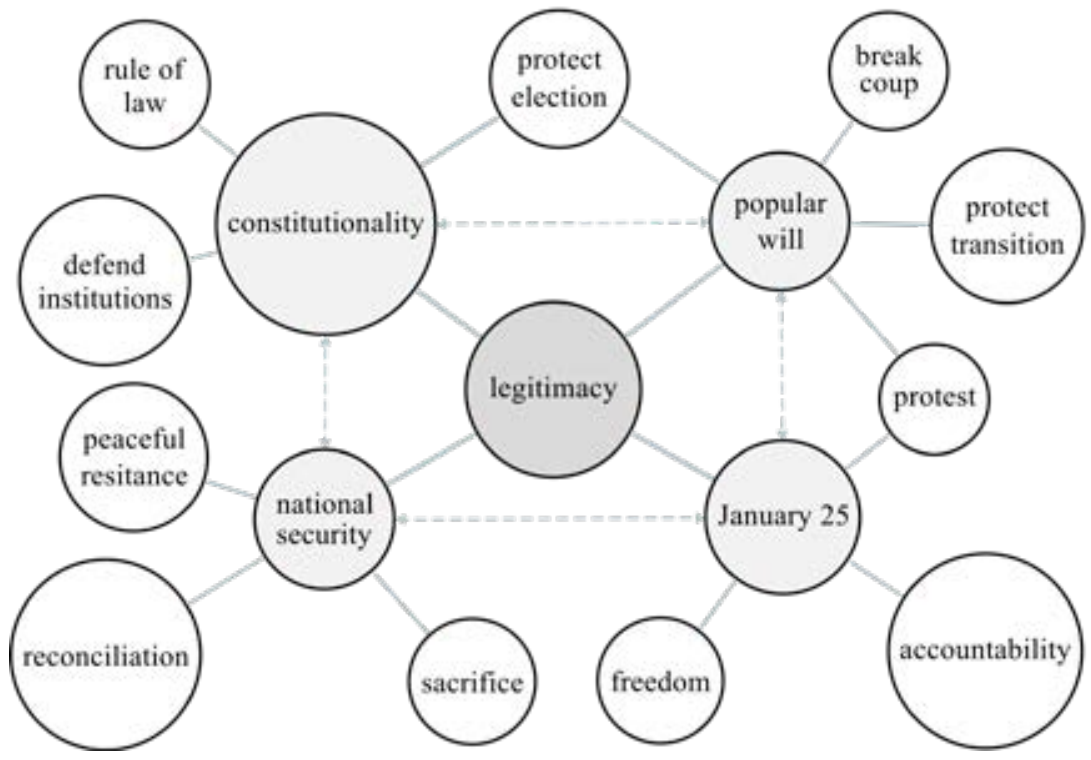

the nationalist-inspired reference to the defense of legitimacy as a service to national security, in turn, derived the strong insistence on peacefulness and the (at least official) support for reconciliation. And from the definition of legitimacy as one rooted in the January 25 Revolution derived demands for freedom, social justice, and accountability, as well as an insistence on protest as a mechanism for leveraging popular support.

The alliance's prognosis of what was to be done and how it was to be done, hence of the appropriate strategies of resistance reflected these convictions. This is exemplified by the fourth NASL statement, which was released shortly before Mursi's ouster on July 3 and stressed that adherence and protection of these pillars of legitimacy would ensure that there would be "no fighting or violence or any kind of bloodshed" (NASL, 2013b).

\section{Pillars of Legitimacy}

The NASL realized that it had been the narrow conception of popular will as the periodic formal expression of voting preference at the ballot, which had undermined first Mubarak's and then Mursi's claim of representing the people. It therefore additionally drew on conceptions of revolutionary legitimacy which had been developed via street politics during the 20112012 uprising. References to the January 25 Revolution recall, above all, a 
range of historical descriptions of who acted how towards whom during the 18 days of the Tahrir Square occupation in 2011. However, January 25 can also be conceived of as the signifier for a more abstract belief system and a repertoire of interpretive frames loaded with cultural and affective meaning. Tarek Ghanem (2016) has deployed the metaphor of religion to describe this symbolic layer of January 25. He points to the ideals of agency, autonomy, and moral consistency, the emotions, and affective memories, and the rituals and iconography (embodied in the martyrs and their stories and legacies), which the term evokes.

Though the metaphor is debatable, the Tahrir revolution, as a symbolic marker, has come to embody the essential elements of a belief system with enormous mobilizing power. By arguing that "the great revolution continues all the areas and quarters of Egypt until achieving its goals and making it clear that it will never allow the defunct former regime to return" (NASL, 2013a), the Anti-Coup campaign drew on this belief system to reinforce its claims. The alliance thereby placed its resistance to the coup in the trajectory of the Egyptian revolution against authoritarianism: as a committed coalition of Egyptian citizens who continued to uphold the spirit of the revolution, the NASL would neither allow legitimacy to be overturned nor a return to "the age of dictatorship, corruption, and tyranny" (NASL, 2013b).

Betting on the power of collective memories about the 2011 uprising, the alliance moreover drew parallels between its victimization and the violent crackdown on Midan Tahrir. It emphasized that, in 2011, thousands of Egyptians had fallen victim to the same kind of violence that its members were now experiencing (see NASL, 2013d). This effectively likened the Anti-Coup martyrs to the canonized martyrs of the Tahir uprising. After instances of violence and bloodshed, these references became more explicit, such as on the day before Mursi's ouster on July 3 , when clashes between demonstrators, residents, and police forces at a pro-Mursi rally near Cairo University left 18 dead (see Human Rights Watch, 2013a). The Alliance reacted to these clashes by extending its condolences to the families of all those who had been killed, both supporters and opponents of its cause. In its letter of condolence, it portrayed the fatalities as martyrs and ignored the fact that the violence had resulted from civil strife. Instead, it highlighted that the clashes had unraveled "under the eyes and ears of the security apparatus" (NASL, 2013d). Additionally, it pointed out the similarities with Mubarak's infamous attempt to disperse the crowds on Tahrir Square with the help of hired thugs on camelback on February 2, 2011 - one of the most iconic events of the Tahrir occupation. 
Such parallels between the early days of the 2011 uprising and the beginning of the crackdown on the Anti-Coup campaign were not only drawn by the public relations professionals within the NASL but also at the movement's grassroots level. Several interview partners have acknowledged that the violence in the summer of 2013 was premeditated given the climate of anxiety, dehumanization of opposing sides (see also Schielke, 2017). However, they also stressed that initially their perception of the struggle was shaped by the categories of their prior revolutionary experience. One research participant recalled that he and his comrades had stood "as one" on Abdel Moneim Riyad street, one of the entrances to Tahrir Square, against the hired thugs in 2011. In 2013 he felt like he and his comrades were standing against them once more, only this time in Gizah, the site of the Al-Nahda encampment. ${ }^{4}$

Lastly, the defense and protection of national security also became a nodal signifier in the Anti-Coup Alliance's discourse on legitimate resistance. This was undertaken to counter the coupists' attempts to monopolize the prerogative of interpretation over what was to be considered sensitive to national security and which elements were a threat to it. Furthermore, such rhetoric also served to discredit alternative resistance strategies against the coup which were not primed on nonviolence. The adoption of a prognostic frame that stressed peaceful protest as the only legitimate means of resistance had a strong prefigurative component in that it expressed the political ends of the Anti-Coup campaign - a return to civil rule and a peaceful rotation of power - through its means (see Yates, 2015). From the outset of their campaign, the alliance thus affirmed its "full commitment to the principle of peacefulness established by the glorious January Revolution." Bloodshed was a "red line" that was not to be crossed (NASL, 2013a).

\section{Constructing the Antagonist Other}

This red line divided the NASL from its antagonist other. This adversary was constructed around the nodal signifier of the coup. Mursi's last presidential address had set the parameters for who was to be considered to be part of this coup. Only moments after General Al-Sisi had announced Mursi's ouster, the president released a hastily recorded video clip on an official Website, in which he denounced the coup attempt. Moments later, the website was shut down, and the record disappeared, as official media channels refused

4 Group discussion with two young Muslim Brothers and the son of a Gamaa Islamiya member, July 2014 . 
to televise Mursi's statements without permission from the armed forces. ${ }^{5} \mathrm{~A}$ shortened transcript was later e-mailed to selected reporters and researchers. It asserted that the actions of the leadership of the armed forces represented a military coup. In his capacity as the high commander of the armed forces, the president insisted that all citizens, "whether civilian or military, both commanders and soldiers" should adhere to the constitution and reject this coup that only led Egypt backward. ${ }^{6}$

He also affirmed his earlier view that an unholy alliance between remnants of the old regime and a fifth column of criminals, corrupt instigators, and secretive groups had colluded to sabotage Egypt's democratic experiment. In his anniversary speech on June 26 , Mursi had alleged that this nefarious counterrevolutionary coalition was supported from abroad (see Mursi, 2013b). After Mursi's deposition, the NASL adopted this definition of the national enemy as an axis of four different counterrevolutionary players (see Figure 4). These included:

1 The coup regime, which denoted the coup leaders on the institutional level and the public figureheads of the military intervention, Defense Minister Abdelfattah Al-Sisi, Interior Minister Mohamed Ibrahim, the state security institutions, as well as the Ministry of Interior and its subordinate law enforcement and policing bodies.

2 A clandestine fifth column consisting of old regime remnants, the remaining fractions of Mubarak's National Democratic Party, and their domestic and foreign financiers, which were trying to cause chaos and sectarian strife to destabilize the country and enable a return to the pre-revolutionary order.

3 The opposition forces, including the Tamarod movement and the parties and initiatives bundled in the National Salvation Front, who had violated the constitution by voicing their dissent outside of the institutional channels for democratic expression; as well as the larger part of private and state media who, according to the NASL, were abrogating their professional ethics for a role as a public address system for the coup forces.

4 Criminals and hired thugs, including the so-called baltagiya who, in Mubarak's time, used to swarm Egypt's neighborhoods during elections to intimidate opposition candidates, and who developed into key agents of state repression since the 2011 uprising.

5 Neither an official record nor a full original transcript of the speech exists. This is the primary reason why this "last stand" is usually overlooked by analysts who mistakenly refer to Mursi's address on June 2, 2013 as his last speech.

6 A copy of the e-mail received on July 3, 2013, at approximately 10 p.m. Cairo time, is on file with the author. 
Figure 4 Construction of antagonist other in the Anti-Coup discourse

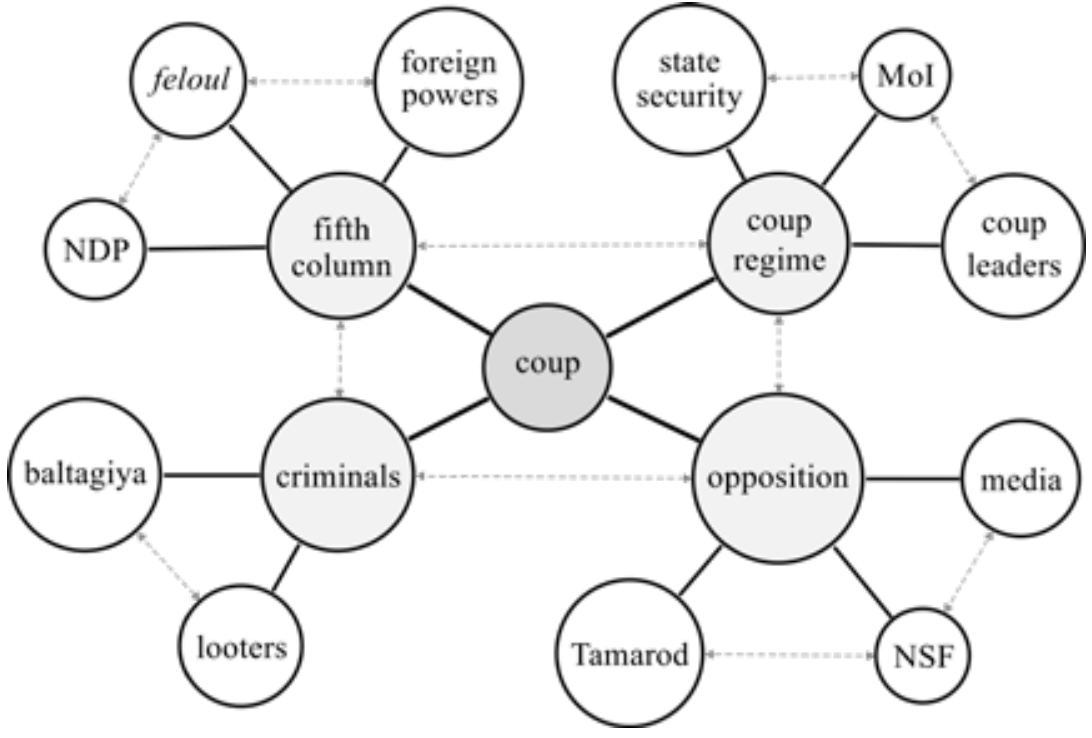

Significantly, the armed forces were not included in this nefarious quartet. Quite the contrary, at first, the NASL explicitly welcomed the army's presence in the street and called upon the troops to prevent attacks on protesters just as they had done during the Tahrir uprising. The alliance even downplayed prior confrontations between Islamist protesters and army forces as mere misunderstandings that the NASL was keen to avoid from now on (see NASL, 2013c). Many of the NASL statements addressed the members of the armed forces as "fellow officers" thus deliberately constructing a relation of equivalence between the soldiers and the members of the Anti-Coup campaign. This conciliatory tone was surprising, as the alliance concurrently framed the cascade of events between June 30 and July 3 as an inqilab 'askariy - a military coup d'état - making use of a terminology that implied the armed forces' involvement. Explicitly, however, it refrained from calling out the generals as the chief perpetrators and, instead, emphasizes the military's role as a people's army.

\section{People's Army versus Police State}

This reluctance to alienate the military can be explained by the NASL's lack of allies within the security sector. Numerous media sources had 
documented the resentment that had permeated the officers' corps of the Ministry of Interior during Mursi's year in office (Alsharif \& Saleh, 2013). Furthermore, police officers had assisted in the collection of signatures for the Tamarod petition and adopted a wait-and-see approach vis-à-vis the Mursi administration. At times, the police had even openly opposed the Mursi administration, such as during the Ittihadiya Palace clashes discussed in the previous chapter. In June 2013, it also refused to protect the Brotherhood's headquarters in Cairo's Moqattam district as well as FJP premises across the country from looting and arson. ${ }^{7}$ The Ministry of Interior's partisan stance against the acting government became obvious during the coup itself when it unilaterally deployed against the pro-Mursi demonstrators. In a division of labor of sorts, a command within the Egyptian armed forces took Mursi into custody, while the police cracked down on the Brotherhood's demonstrations and relieved the armed forces of the need to make use of their arms.

The NASL's congenial stance towards the armed forces thus partly resulted from its sheer lack of alternatives. Hoping for army units to act as a buffer between Egypt's notorious riot police and the demonstrators, the square leadership of the Rabaa and Al-Nahda camps invited the soldiers to join the sit-ins as brothers and fend off attacks on a constitution that, in the view of the NASL, had preserved the army's central role in Egyptian politics. Keenly aware of its lack of sympathies in the upper army leadership - laid bare by recurrent informal meetings between army officers and Ministry of Interior officials at their social clubs throughout spring (see Alsharif \& Saleh, 2013) - the alliance turned, above all, to the mid and lower ranks:

We harbor only love and appreciation for the officers, the non-commissioned officers, and the soldiers of the armed forces ... you are always an object of honor and pride. We do not forget your role in the recuperation of Sinai in the 1973 war, and we do not forget your support for the glorious Egyptian Revolution on January 25. (NASL, 2013C)

The glory of the armed forces was juxtaposed in opposition to the savagery of the police forces who were portrayed as foot soldiers of the coup. Through the term dawla bulisiya [police state] the alliance characterized the Ministry of Interior as the central villain (NASL, 2013d, p. 6). In addition to domestic security and the coup leaders around Al-Sisi, the NASL also blamed hired

7 A record of the press conference is available at https://www.youtube.com/watch?v=EArLLae99Jw. 
thugs for the violence. As the looting and arson of Brotherhood premises increased and clashes in the vicinity of the Cairo University left 18 dead, the NASL began to refer to the police forces as mugrimin muhtarifin [professional criminals].

Moreover, in an aggressive demarcation of bodies, the NASL vilified as baltagiya all civilians engaged in clashes with its supporters. The term baltagiya originally refers to the Mafia-like structures in many of Cairo's settlements which exist largely outside the supervision of the state. In the past, these structures reliably produced muscles-for-hire, whose services could be contracted by state institutions, local public servants as well as private businessmen (Amar, 2011, p. 308). During the January 25 Revolution, these groups transformed into an instrument of state repression in a dual sense. On the one hand, the baltagiya became a tool to anonymously attack protesters after police forces had retreated to their barracks (Hanafi, 2015). This repression by proxy enabled the regime to confront protesters without corroborating their claims of oppression (see Schwedler, 2018, p. 81). It also allowed the regime to deny responsibility for the violence on the ground. At the same time, the presence of para-state producers of violence in public spaces could be used as a pretext to extend the security apparatus's use of force.

On the other hand, the baltagiya-label became an expedient label to discredit social movements, vilify political currents, and undermine subaltern politics. As Paul Amar (2011) argues, "protesters were re-signified as crazed mobs of brutal men, vaguely 'Islamist' and fiercely irrational" (p. 308). The politics of signification during the revolutionary moment in Egypt effectively blurred the lines between who was a thug and who a revolutionary: "Since all protestors were outlaws, everyone became a thug" (Wahba, 2020, p. 84). However, the delegitimizing essence of the baltagiya label remained intact despite its politicization and was reproduced in Egypt's post-revolutionary arena by a variety of players. After the 2013 coup, both camps attempted to monopolize usage of the derogatory term to discredit their adversaries' policies as a relapse into the barbarism of the Mubarak era.

The NASL alluded, furthermore, to the machinations of a fifth column, a clandestine subversive faction that aimed to undermine the nation's unity by any means at their disposal. In line with Pratt's findings (2015, p. 49), this domestic fifth column that threatens the fabric of the nation through its particularistic interests found its complementary counterpart in the hidden hands of dangerous foreign forces. Unspecific hints to external actors as a "third hand" or as "foreign fingers" - today common tropes in 
the xenophobic discourses that are promoted by nationalist TV shows and official statements in Egypt - were a characteristic feature of the NASL statements.

As Wessel (2018) has suggested these "third hand"-claims represented a particularly powerful rhetorical vehicle: "Since the 'enemy' or the 'other' is so elusive and depends on the interpretation of the individual, it enables the incorporation of a wide range of competing and even opposing collective imaginaries" (p. 353). According to the NASL, the nefarious alliance plotting against the people consisted of both, remnants of the old regime, such as Mubarak's National Democratic Party, as well as foreign powers, including Zionist agents, who collaborated to destabilize the country and prepare the return to the pre-revolutionary order.

In a press release on the eve of June 30, the NASL leadership alleged that the Tamarod movement was colluding with these forces. The statement not only decried the political violence and killings, and the looting of the FJP's offices during the past weeks. It also bemoaned that the attacks with blades, live bullets, birdshot, and Molotov cocktails clearly showed that the "NDP thugs and their NSF and Tamarod allies [...] had no respect for the sanctity of homes and private property" (Muslim Brotherhood, 2013a). It claimed that supporters of the Tamarod campaign had attacked NASL leaders' houses and shops across Egypt and even laid siege to mosques. Other players were complicit in these attacks, the statement stressed, by remaining quiet and implicitly condoning this violence. This also included the media which, according to the NASL, had failed to adhere to professional standards by not covering the attacks.

Here the NASL picked up Mursi's cue. In the last speech before his deposition, Mursi had alleged that the media was playing a crucial role in the counterrevolutionary efforts that, ultimately, would lead to his demise. After Mursi's ouster, the alliance elaborated on this role in a statement about the "coupist media broadcasting" which accused Egypt's publishing houses and television broadcasters of slander and intentional misrepresentation of the peaceful Anti-Coup protests (NASL, 2013f.). The statement also called on the remaining free media in the country to attend the demonstrations as neutral observers and to oppose the skewed image that the coup forces were promoting.

\section{Mirror Images}

The depiction of the coup forces mirrored the NASL's self-portrayal (see Figure 5). This was particularly so on the diagnostic level where the 
Figure 5 The coup as a mirror image of the Anti-Coup resistance

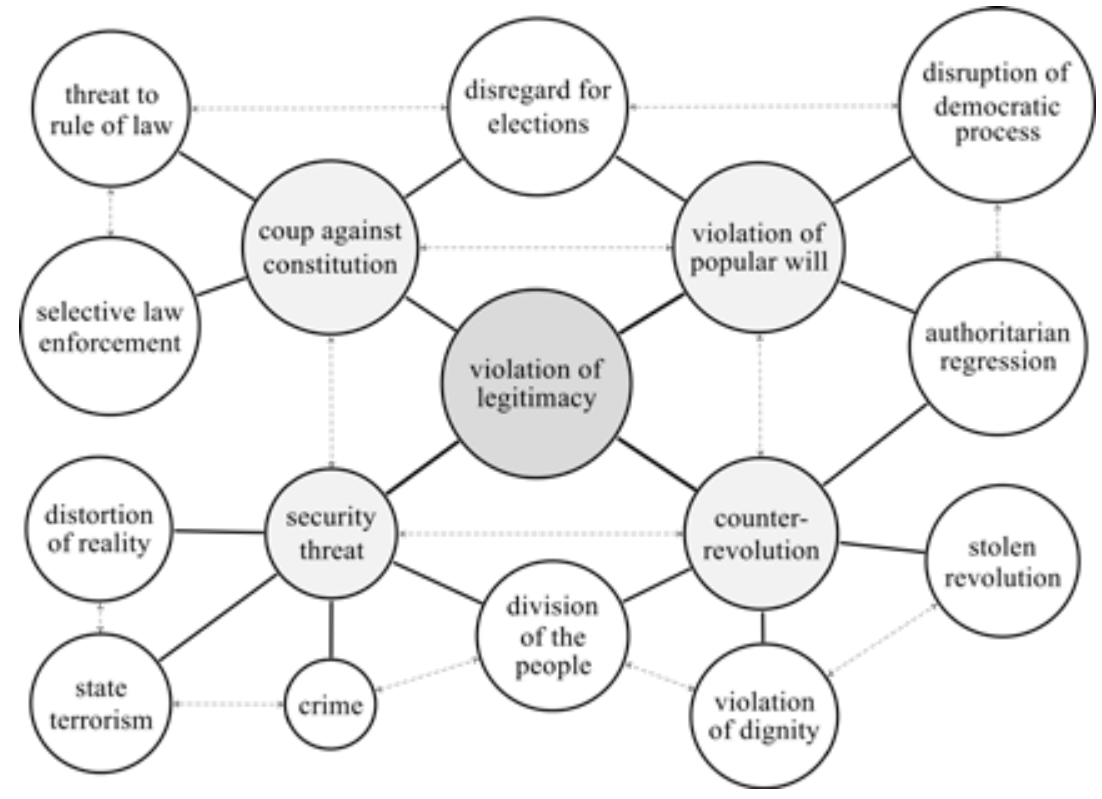

Anti-Coup Alliance enumerated the coup forces' actions. Here the popular will, constitutionality, national security, and the January 25 Revolution again assumed the roles of nodal signifiers. According to the NASL, the players that supported the coup had undermined precisely these foundations of legitimate rule by acting against the popular will to champion a counterrevolution, and by setting themselves above the roles provisioned for them in the constitution. Above all, the state institutions aligned with the coup were neglecting their constitutional purpose: Security forces were failing to protect protesters as well as FJP offices from attacks. The media were not abiding by the norms of professionalism and decency as stipulated in article 215 of the constitution by spreading misinformation. And the armed forces were overstepping their mandate to protect the homeland by adopting a partisan role and partaking in a vicious defamation campaign against one group.

On the other hand, the NASL claimed, the coup forces were threatening the rule of law. By forcibly deposing President Mursi, they had ignored the constitutional process to replace the head of state, either via democratic elections or via impeachment. Article 152 specified that the removal of Egypt's head of state was conditional on a motion signed by at least one-third of the members of the Council of Representatives and a two-thirds majority vote. 
Aside from a threat to the rule of law, the NASL referred to the coup also as an imminent threat to the integrity and security of Egyptian society. National security effectively became another central signifier in the alliance's discourse about its antagonist other. The NASL based this diagnostic framing crucially on three arguments: First, it asserted that the coup was pitting "the people against the army on the one hand, and against each other, on the other hand" (NASL, 2013j), thus eroding the popular unity achieved through the joint revolutionary struggle as well as the social contract between the Egyptian people and its armed forces. Second, it warned that the incitement of civil strife during this critical juncture would only benefit Egypt's domestic and foreign enemies (see NASL, 2013g). And third, it underscored that the use of state violence against protesters provided a pretext for a return of the security state and a rollback of the rights and freedoms that had been won during the 2011 uprising.

Within this security frame, the security service's (in)actions were interpreted as symptoms of reemergent state terrorism. These symptoms included the closure of Islamist media channels, the illegal arrest of opposition politicians, a campaign of lawsuits against Brotherhood members, and former government officials, as well as the restriction of public spaces for protest. This rhetoric only hardened when clashes between Anti-Coup protesters and their opponents intensified, and the police started to confront protest marches more forcefully. When riot police brutally cracked down on the Anti-Coup demonstrations on Friday, July 5, 2013, the NASL began to openly accuse the coup forces of murder (see NASL, 2013e, 2013f.).

\section{First Blood}

The Friday of Rejection on July 5, 2013, became the first turning point event for the Anti-Coup campaign. The NASL had called for nationwide protests on this day. In Cairo, these protests concentrated on the periphery of Salah Salem Street, which houses the Republican Guard headquarters. Ostensibly, the Republican Guard is directly subordinate to the president of the Republic, but it had been members of this military division that had taken President Mursi into custody. Consequently, Anti-Coup demonstrators believed the deposed President Mursi was held in their headquarters and erected tents in front of the barracks directly after Mursi's deposition was announced. After the Friday sermon, thousands of additional demonstrators marched to the barracks, answering calls by the Brotherhood's murshid [supreme leader] Mohammed Badie who had unexpectedly appeared at a rally in eastern Cairo and insisted that street mobilization would continue until Mursi's 
reinstatement. Overwhelmed by this mobilization, riot police resorted to live ammunition to confront the marches, killing at least three and injuring several more.

Violence also intensified at other demonstrations as Mursi supporters clashed with their opponents in central Cairo, Alexandria, Beni Suef, Damanhur, and Luxor. In most of these situations, the police forces sided with Mursi's opponents. At times, they merely provided cover and shielded anti-Mursi demonstrators with their vehicles (Escobales et al., 2013). In other instances, they engaged in physical violence themselves. In many cases, police simply remained absent from the scene for hours. As a result, the clashes lasted until the early morning hours and left dozens of protesters dead and over a thousand injured.

Investigations have highlighted that violence on the night of July 5 emanated from all sides (Human Rights Watch, 2014, p. 108ff.). But the consequences were particularly severe for the Anti-Coup Alliance. Graphic videos of Mursi supporters stabbing their opponents and throwing them off the roof of a building in the city of Alexandria undermined the NASL's insistence on peaceful resistance. On Rabaa Square, these videos were relativized as self-defense or denounced as false flag operations. To rectify its public image, the NASL even alleged that the security services had paid bearded baltagiya to wreak havoc in an attempt to frame Mursi's supporters as extremists (see NASL, 2013g). But outside of the NASL support base, these justifications did not resonate. Most Egyptians were simply appalled by the brutality they had witnessed.

Consequently, the events on July 5 contributed to the development of a siege mentality within the Islamist camp. They confirmed the worst fears of the Anti-Coup organizers who had repeatedly cautioned against an upsurge in violence, should its demonstrators remain unprotected. At the same time, their aftermath substantiated the NASL's perception of its adversary as an alliance of security forces and media in the cover of a popular uprising. For the Anti-Coup members, their collusion was evidenced by the fact that neither the army nor police had intervened for hours to prevent factional violence, and by the fact that the media had assigned responsibility for the clashes solely to the Anti-Coup protesters.

These suspicions were additionally fed by Tamarod and the National Salvation Front who responded to the July 5 clashes with statements that portrayed the Anti-Coup campaign as a violent revolt against the glorious second revolution on June 30. For the NASL, this appropriation of the revolution metaphor whitewashed the coup on July 3, 2013. In an attempt to counter this narrative, it insisted that Tamarod had violated the people's 
dignity by inviting the army to return to the political playing field and asserted that it would not allow a return to the age of dictatorship. As the NASL adopted this diagnosis of July 3 as a regression to autocracy, the depiction of Mursi's opponents as counterrevolutionaries became central to the Anti-Coup resistance discourse.

\section{The Republican Guard Massacre}

The internal frontier constructed by the NASL between the supporters of legitimate democratic rule, on the one hand, and the counterrevolutionary coup forces, on the other, crumbled as it became increasingly evident that the armed forces could not be relied upon as a neutral mediator. The army's partiality was apparent on July 5, 2013, when many of the tanks that were deployed across the country carried anti-Mursi demonstrators on their roofs to the frontlines. But it became undeniable when army units, for the first time since Mursi's ouster, deployed lethal violence against protesters themselves. Supported by riot police, they began to clear the Anti-Coup sit-ins in front of the Republican Guard headquarters on the night of July $7-8$, 2013. It is estimated that, at the time, some 2,00o people were camping on Salah Salem Street (Kingsley \& Green, 2013). Hundreds of these Anti-Coup protesters were injured or arrested during the raids. In addition, more than 90 protesters were killed by live ammunition - fired from the rifles of elite army units. ${ }^{8}$

To justify this deadly use of force, the military claimed that the security forces had only acted in self-defense against armed protesters who had tried to break into the barracks. ${ }^{9}$ But video evidence and eyewitness interviews tell a different story, namely that of a coordinated assault of Republican Guard units and the paramilitary Central Security Forces (CSF) on the protesters (Amnesty International, 2013a). Videos uploaded by neighbors of the sit-in contained only a few images of protesters hurling stones and Molotov cocktails towards the security forces. ${ }^{10}$ But they clearly document

8 Wiki Thawra has documented a total of 93 victims, 1,200 injured, and more than $65^{\circ}$ arrests.

9 According to a police report by the Cairo General Investigative Bureau (No. 9134/2013), armed terrorists had attacked the Republican Guard with motorcycles, shooting live ammunition and birdshot and throwing stones from neighboring buildings toward the Republican Guard base. In response to this attack, the army and CSF units protecting the base had used sound bullets and teargas to disperse the responsible groups. The report is available at https://nchrl.org/sites/ default/files/Police\%2opreparator.pdf.

10 See, for instance: https://youtu.be/A31XI7_wl-s; https://youtu.be/-iND9GsCGhU; https:// youtu.be/kKrqk2P4Bvo. 
the use of automatic weapons by uniformed and plainclothes officers and army units against the protesters.

This use of deadly force sparked harsh criticism even among those players who had backed Mursi's ouster. The Salafi Nour Party - a former ally of the Muslim Brotherhood who had sided with the army on July 3 - announced its retreat from the negotiations about an interim government. Shortly thereafter, Hazem Qandil stepped down as interim prime minister. Tellingly, his resignation letter included an apology to the deposed President Mursi for not having resigned directly after his ouster. Even players closely aligned with the armed forces, such as the representatives of Misr Qawiyya [Strong Egypt], Tamarod, and the National Salvation Front demanded an impartial investigation into the shootings.

\section{The Specter of the Deep State}

The killings that are commonly referred to as the "Republican Guard massacre" (P. Owen \& McCarthy, 2013) heralded a new phase in the Anti-Coup Alliance's political subjectivation process. Most importantly, they created a dislocation in the Anti-Coup discourse (Figure 6, new elements shaded in grey). Thus far, the alliance had deliberately excluded the armed forces from the portrayals of its adversary. But the sight of army units shooting unarmed protesters was an event that could not be incorporated into the horizon of expectations evoked by this discourse. The "betrayal" of the armed forces came as a shock to many Anti-Coup protesters. It impacted heavily on protesters' affective loyalties in that it undermined trust and disenthralled long fostered feelings of love and belonging (see Jasper, 2018, p. 103ff.). It also seriously challenged the NASL's narrative of the armed forces as a neutral people's army.

To suture this rift, the Anti-Coup discourse needed to shift. On July 8, 2013, for the first time, the Anti-Coup Alliance explicitly called out the armed forces for their actions:

The hideous massacre was committed by the Egyptian Army and police against peaceful protesters from among the sons of the great Egyptian people, praying the Fajr, in a crime that is unprecedented in Egyptian History. It resulted in dozens of martyrs, including children and infants who died at the breasts of their mothers, and hundreds of injured. (NASL, 2013h)

In this characterization of the events, we have the unprotected pious victim of the children and mothers, who are attacked by the powerful villain of the coup forces, aided by the minions of the army and police. In later statements, 
Figure 6 Construction of antagonist other after the Republican Guard Massacre

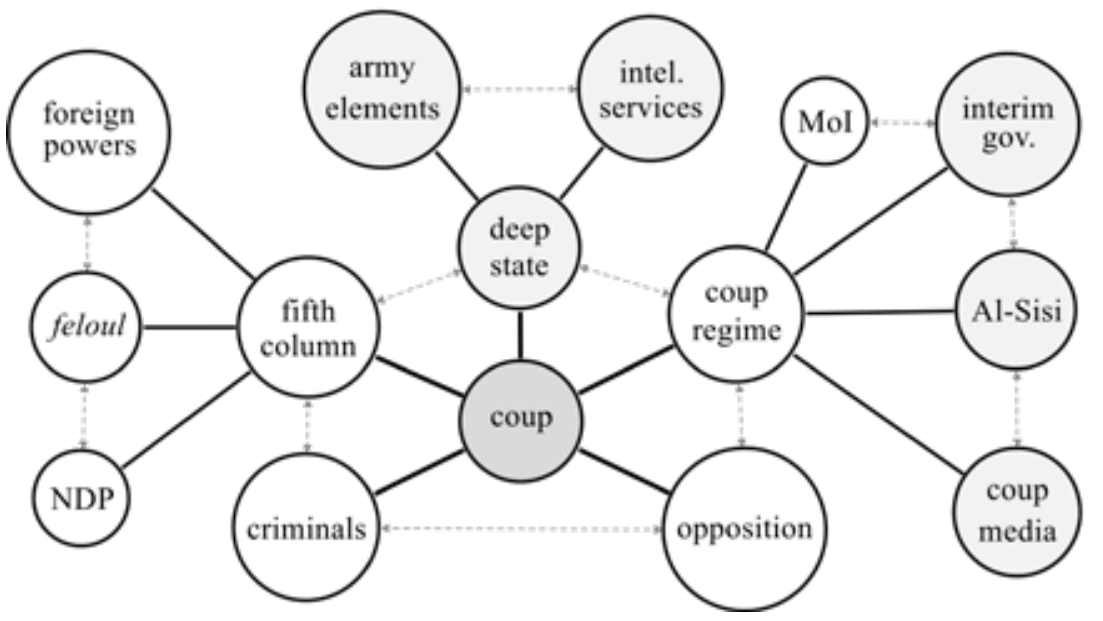

this cast was completed by the heroes of the Egyptian people whom the Anti-Coup Alliance called upon to join the ranks of the opposition. This topical character work provided an organizing principle by which the actions of players on both sides of the antagonist divide could be linked together and made sense of (see Jasper et al., 2020, p. 2ff.). The Anti-Coup press releases about the massacre were also unprecedented in their moral excoriation of the armed forces. They stressed that the army had dishonored itself by violating all religious values and moral norms. Not thugs or gangsters but soldiers and officers had fired live bullets into crowds of worshipers. This repugnant crime made the army an accomplice of the coup and placed it on the opposite side of the frontier drawn by the protesters between the coup forces and the resistance. Over the coming weeks, the armed forces moved from the least questioned player to the most prominent foe in the Anti-Coup narrative.

Notably, even after the Republican Guard massacre, the Anti-Coup discourse retained a backdoor for reconciliation - at least, with the lower ranks of the army. It categorically distinguished between those giving and those merely acting upon orders. In several letters to their "brother officers and soldiers," the NASL organizers stressed that its protesters had no quarrel with the members of the armed forces themselves. Their conflict was with those commanders who involved the army in politics and aimed for a return to direct military rule:

We are all Egyptian citizens, military and civilian, we are all brothers in our homeland. Among you are some brothers of kin. We were also part of 
the military during our military service. We were proud of the uniform and proud to belong to this ancient national institution. You will become civilians again after the end of your service. You are part of us, and we are part of you. (NASL, 2013l)

To maintain this strategic distinction, even when army operations against street protests became more frequent, the Anti-Coup organizers concentrated on their framing of Abdel Fattah Al-Sisi and his aides - the coup leaders - as the main culprits. During the July 3 coup, the Republican Guard had acted under Al-Sis's direct orders when it took Mursi into custody. That the elite unit was now also involved in the killing of protesters facilitated framing the General as the mastermind behind the democratic rollback. In addition, the NASL exculpated the military rank and file by adopting vague references to the machinations of an alleged deep state that was controlling the state's actions.

The term deep state [ad-dawla al-'amiqa] carries multiple connotations. On the one hand, it has traditionally denoted a secretive authoritarian substructure of republican politics behind institutional façades. As such it aptly described how power was exerted in Egypt's "officer republic" (Sayigh, 2012) until the fall of Mubarak. Since the 1950s, a quiet entente between the presidency, the security services, and the army had functioned as a political gatekeeper. As Springborg (2018, p. 71) argues, power shifted marginally between the three legs of this tripod, but the tripod itself remained remarkably stable. This power balance allowed the alternating political regimes governing the country to protect the interests of a narrow elite to the exclusion of the majority population. However, it also undermined the separation of power and prevented accountability, thus stalling the much-needed economic modernization.

On the other hand, the deep state represents a discursive figure that belies the scarcity of reliable information about the actual power relations in post-revolutionary Egypt. As an empty signifier, it has become a scapegoat for players on both sides of the political divide. For power-holders, the deep state functions as a bogeyman who is invoked to deflect from their shortcomings. The different republican regimes from Sadat to Mubarak routinely blamed the deep state for Egypt's economic underperformance. ${ }^{11}$

11 Sarah Wessel (2016, p. 18ff.) has discussed a particularly striking example of how the narrative of the deep state was instrumentalized by the Supreme Council of Armed Forces to tarnish the revolutionary movement. In 2012, its government produced two segments for state and private television which cautioned Egyptians against interacting with foreigners. These spots spread 
Parroted by state television and newspapers the term securitized politics by creating the perception of a country under threat of exploitation by conspiring domestic and foreign forces. For contenders, in turn, referrals to the deep state functioned as a vehicle for pointing out the accountability gap before the 2011 uprising. After the Arab Spring, it turned into a prominent excuse for social movements to explain the resilience of authoritarian structures (see Hanafi, 2015).

Alongside similar expressions, such as the "third hand" or the "fifth column," the term also became an effective rhetorical tool to discredit specific players and their actions as controlled by foreign powers (Wessel, 2016). During Mursi's time in office, references to the deep state became such common currency that not only progressive activists, but also Mursi's conservative supporters claimed that the president was constrained in his policies and reform efforts by the tight grip of a counterrevolutionary deep state alliance. Mursi himself adopted this trope in his last public speeches (Mursi, 2013c).

The NASL hence drew on a well-established archive by invoking the deep state as the master puppeteer who was pulling the strings in Egypt's political theater - and to discredit the interim regime which was solidifying rapidly: Only a few days in office, interim President Adly Mansour issued a timetable for the transition period. He also swiftly appointed a technocratic transition government led by the respected economist Hazem El-Beblawi. ${ }^{12}$ NSF leader Mohamed El-Baradei was appointed to the post of vice-president. These swift attempts to institutionalize the new status quo can be understood as an attempt to curry favor with those social players whose protests had paved the way for Mursi's ouster. Additionally, they meant to alleviate fears of a return to direct military rule.

Among the Anti-Coup protesters, however, these steps were discounted as mere window-dressing. A dedicated statement on the day the interim cabinet was sworn in portrayed the new government as an autocratic dictatorship in disguise and highlighted popular elections as the only legitimate means for the Egyptian people to choose their representatives (NASL, 2013k). This

fears of conspiracies by alleging that youth movements were dealing with foreign spies. The clips can be viewed at https://youtu.be/GuclyK94RwI and https://youtu.be/poaHa7Jkxa4.

12 Aside from Prime Minister Hazem Al-Beblawi, the interim cabinet comprised 34 members, including two military and two police representatives. In addition to Al-Sisi, who remained defense minister, Air Marshall Reda Mahmoud Hafez joined the cabinet as minister of military production. Major General Mohammed Ibrahim retained his post as interior minister, and General Mohamed Abu Shady assumed responsibility for supply and domestic trade. 
narrative placed the interim government within the realm of the coup forces, further narrowing the room for compromise in favor of consolidation of political antagonisms.

\section{Closing Ranks}

The victimization by state repression gradually closed the window for reconciliation between the key players in Egypt's protest arena. It also complicated attempts by third parties to act as mediators between the interim authorities and the Muslim Brotherhood. Before the Republican Guard massacre, Egypt's Al-Gama'a Al-Islamiya - a staunch political ally of the Brotherhood - had attempted to break the polarizing political stalemate by calling for reconciliation and negotiations about a general amnesty for all contending factions. After the massacre, such a conciliatory course of action became much harder to justify within the Anti-Coup Alliance. As several exiled participants of the demonstrations in early July 2013 confirmed when I interviewed them in Istanbul, the shared experience of facing police brutality effectively streamlined the narrative within the originally diverse protest coalition. Conversely, the divisions between the antagonist camps became more pronounced, as the alliance resorted to a portrayal of the struggle as a zero-sum game:

The current conflict is not political between parties with different visions, but a struggle between the dream of achieving a civil democratic state and brutal military rule that never in the entire global history has kept a clean slate. (NASL, 2013i)

Aside from galvanizing the Anti-Coup Alliance's collective identity, the Republican Guard massacre also triggered a significant backlash on the part of the Anti-Coup protesters. Collective action notably gained pace with the start of Ramadan on July 10, 2013. During the fasting month, Anti-Coup protesters across the country used mosques as gathering points for their marches and central stages for their rallies (on a comparable function of mosques in other contexts see Olesen, 2009, p. 19; M. Hafez, 2003, p. 36). In the weeks after the Republican Guard incident, protest rates increased steadily until settling at around one hundred larger protest marches per week.

As argued more extensively elsewhere (Grimm \& Harders, 2018), this protest backlash was driven, above all, by the lack of selectivity and the brutality of the security forces. Many victims of the Republican Guard crackdown had been hospitalized with bullet wounds in their thorax, neck, and head regions. 
Investigations suggest that these wounds were caused by both, targeted sniper fire and indiscriminate machine gun use (EIPR, 2014, p. 44f.; Human Rights Watch, 2014, p. 113f.). Moreover, CSF units had poorly timed their operations so that they coincided with the morning prayers, and used heavy weaponry against the demonstrators, causing the death of several women and children (see EIPR, 2014; Human Rights Watch, 2014; Kingsley \& Green, 2013).

Notably among the victims of the massacre were not only members of the Anti-Coup Alliance - let alone armed protesters, as the security forces affirmed - but also residents of the surrounding neighborhoods. Some of these residents had joined the protesters for the morning prayer or had gone to pray in the Mustafa and Sayyida Safiya Mosques which are both close to the Republican Guard barracks. Doctors reported that the bulk of the victims had been barefoot upon their arrival at the hospital - an indication that the attack had coincided with the prayer (El-Dabh, 2013a). This enabled the Anti-Coup organizers to frame the assault as a slaughter of devoted Muslims and to draw comparisons to Syria where an army attack on the Umari mosque in Deraa had precipitated a civil war (see Pearlman, 2018). An Anti-Coup slogan soon branded Al-Sisi as a butcher and compared him to Syrian President Bashar al-Assad (Rahin, 2013).

\section{Burning Bridges}

These narratives, however, never reached the broader Egyptian public. They were thus scarcely able to evoke solidarity or to convince non-aligned political players of the peaceful nature of the Anti-Coup protests. Against the background of a media blackout against the NASL, the massacre narrative generated little resonance. Instead, many in the anti-Mursi camp underreported or relativized violence as a necessary evil to defend public security. As Fatima El-Issawi (2014) argued, "journalists' self-identification as advocates for the 'national interest', translated into the defense of the regime's survival, and prevailed over the timorous movement among journalists after the uprising who lobbied for independent and professional journalism" (p. 302).

Others chose to ignore the killings in their reporting as part of a survival strategy to appease the military (Bolliger et al., 2016). ${ }^{13}$ The few independent newspapers that published evidence that supported the protesters' side

13 Several journalists interviewed during a 2015 field trip to Cairo describe how they were asked by their board or editor-in-chief to tune down the tone of their articles to avoid repercussions. Two recounted that their online articles were taken offline shortly after the release of the army's press statement which contradicted parts of their stories. 
of the story - even against their political stances - found their articles censored or blocked from access (see A. A. Mohsen, 2013). This included the Brotherhood's English and Arabic websites, which served as the NASL's main public relations tools (Richter, 2017), as well as the Brotherhood's Huriyya \& Adala newspaper whose print edition was discontinued by the Al-Ahram Publishing House after the Republican Guard killings. ${ }^{14}$

Meanwhile, state television published a series of video clips released by the military and the Ministry of Interior which rivaled the images circulated by the NASL via social media. ${ }^{15}$ They showed protesters hurling stones from rooftops and bearded men with shotguns and make-shift firearms near the Republican Guard barracks. Albeit heavily edited, these clips fed into the state narrative that depicted the sit-in as a threat, which had been neutralized by the security forces. What is more, the authorities categorically denied the use of lethal violence and denounced all evidence to the contrary as a skilled falsification. According to army spokesman Ahmed Adly, the clips released by the NASL were part of "psychological warfare" against the armed forces. ${ }^{16}$

These and similar claims supported a strategic securitization of the AntiCoup protests on the part of the interim authorities. Coined by a group of researchers of the University of Copenhagen (Buzan et al., 1998; Waever, 1995), the term describes the process of discursive construction that aims at fundamentally altering the public perception of a social player so that she becomes relevant in a security context. Internalized norms and values, as well as the institutionalized rules of peaceful coexistence, are thereby be altered or replaced by new modes of action that follow a strict security logic: In the name of security, extraordinary measures are legitimized that would otherwise be unacceptable - for instance, the domestic deployment of troops against protestors. This is because an issue complex, once successfully securitized, comes to be regarded as an isolated subsystem, where norms and rules that govern society do not apply (see Amar, 2013). The security complex becomes anarchy in its own right. Processes of securitization are supported by certain linguistic structures.

After the Republican Guard clashes, Egypt's "securocratic" institutions (see Abdelrahman, 2017) sought to establish legitimacy for their actions by controlling the rhetoric surrounding the events. To accomplish this task,

15 Wiki Thawra has collected these videos as well as pictures and clips released by third parties on YouTube and different social media at http://bit.ly/2RqRhpW.

16 A full video of the press conference is available at https://youtu.be/xugyag81soM. 
the SCAF and the Ministry of Interior unleashed a propaganda campaign. Claims of an armed attack were soon followed by allegations that weapons were stored at the Rabaa camp and that the Anti-Coup protest sites were harboring radical Jihadist foreign fighters. State television became the interim regime's mouthpiece and increasingly portrayed the Anti-Coup Alliance as an alien body and as a problem that required a security solution.

Such discourses were fueled by the rising number of confrontations in the weeks after the Republican Guard killings. Clashes between AntiCoup protesters and counter-demonstrators as well as organized baltagiya escalated. On July 19, 2013, they culminated in bloody street battles in the city of Mansoura that left several women dead (EIPR, 2014, p. 50). Their deaths tarnished the image of the NASL as a peaceful civic coalition. July 2013 also saw a significant increase in terrorist attacks on police stations and checkpoints within the Nile Valley and on the Sinai Peninsula, as well as an assault on Coptic Christians in Southern Egypt. Though the Muslim Brotherhood condemned this spike of sectarian violence (NASL, 2013p), the attacks nourished suspicions that the group, in a division of labor, had joined forces with Jihadi groups to destabilize and bring down the government.

More significantly, the growing feelings of vulnerability and insecurity among the Egyptian population gradually turned the general atmosphere against the protests (see Osman, 2013b). This, in turn, lowered the costs of policing: As collective actions continued to disrupt urban transport, blocked major thoroughfares, and forced business activity to a near halt, authorities could argue that the police only fulfilled its mandate to restore law and order when it took action against protesters (see Rivera Celestino, 2012, p. 6). Rumors that the NASL was hoarding weapons and operating torture chambers, in turn, became the pretext for raids of the FJP party premises across the country. Sanctions against critics of this crackdown were justified as measures against disinformation and incitement (M. Mohsen, 2013).

The securitization of the Anti-Coup protest was backed by judicial proceedings against the NASL leadership which was declared the principal suspect of an investigation into the Republican Guard killings. According to General Prosecutor Hisham Barakat, the Anti-Coup leaders had incited violence against demonstrators on several occasions and "ordered armed groups to cut off highways and threaten violence" (Abedine \& Abdelaziz, 2013). This accusation paved the way for the imposition of far-reaching travel bans and asset freezes. It also clearly aimed at isolating the protest leadership from its base.

This attempt to drive a wedge into the movement was flanked by conciliatory remarks vis-à-vis the Anti-Coup grassroots. Army spokesman Ahmed 
Ali addressed the squatters on Midan Rabaa and Midan Al-Nahda as brothers and signaled general willingness to engage in reconciliatory measures. ${ }^{17}$ In a similar vein, Interim President Mansour took the anniversary of the July 23, 1952 revolution as an occasion to invite Egypt's political players to set aside their hatred and divisions and join a national dialogue to "turn a new page" in the country's history ${ }^{18}$ But these reconciliation initiatives were emphatically rejected by the Anti-Coup organizers who stressed that Mursi was the only legitimate host for any sort of national dialogue (Nagi, 2013b). The movement would not contribute to a consolidation of the status quo by accepting the interim institutions as dialogue partners. Following this rebuke, the president's conciliatory rhetoric gave way to more confrontative discourse that vilified all protesters as enemies of the state.

\section{A Popular Mandate for Repression}

Abdel Fattah Al-Sisi's speech on July 24, 2013, at a military graduation ceremony marked the turning point for the government's strategy vis-à-vis the Anti-Coup movement. Delivered in response to a deadly bomb attack on the Mansoura police station and broadcast live by state media, the general's remarks turned into a rallying cry. In an attempt to restage the dynamics that had empowered the army to depose Mursi, the speech emphasized the inseparable relationship between the Egyptian people and their armed forces, summoning the revolutionary myth of the army and the people as "one hand" (see Ketchley, 2014). Festooned in full military regalia, Al-Sisi urged Egyptians to celebrate this unity by taking to the streets in support of the security forces once more on June 26, 2013:

I ask all trusted and honorable Egyptians to come out next Friday to give me the authority to face violence and terrorism. I have not asked anything of you before, but now I ask you to come out and remind the world that you have demands. [...] Please Egyptians shoulder your responsibility with me, the army, and the police. Show your steadfastness in the face of what is going on. ${ }^{19}$

17 A full video of the press conference is available at https://youtu.be/xugyag81soM.

18 See full speech at https://youtu.be/GxI31_ICOmA.

19 For a full record of Al-Sisi's speech visit https://youtu.be/RXYOq47fvAs. A transcript is available at https://archive.is/wip/ZDKmm. 
This call for a popular mandate to confront violence and terrorism capitalized on the widespread feelings of fear and uncertainty and aimed to turn these reflex emotions into affective commitments that supported the authorities' course of action. It can also be interpreted as the first comprehensive effort to present a counter-narrative to the NASL's legitimatization of resistance through street protests. Al Sisi's appeal exemplified how two different conceptions of legitimacy were effectively clashing in Egypt's divided public sphere (Al-Awadi, 2013, p. 549). Whereas the Muslim Brotherhood and its alias invoked the input legitimacy, granted to its President and party through the electoral ballot, Al-Sisi justified the military's intervention into politics with the Mursi administration's missing throughput and output legitimacy.

The signifier of irada al-sha'abiya, the popular will, played a central role in Al-Sisi's attempt to challenge the Anti-Coup discourse: From his first day in office, according to the general, Mursi had failed to rule as a "president of all Egyptians." He had refused initiatives to contain the political crisis through inclusive consultations among all political players. At last, Mursi had also ignored the massive turnout on June 30, 2013, which, according to Al-Sisi, equaled ignoring the will of the people (see Abdel Ghaffar, 2013). The implications of this exclusive rule were clear: Mursi had forgone his right to govern in the name of the people. This right had been revoked through a popular revolt on June 30. Millions of protesting Egyptians had left the military - the guardian of popular sovereignty - with no choice but to intervene.

Al-Sisi's speech reproduced the antagonist logic that had governed political subjectivation within the Anti-Coup camp. His remarks did not explicitly name any one political faction. But they portrayed Egypt's protest arena as one populated by two irreconcilable antagonists - the people and a group of religious fanatics who were turning Egypt into "a battlefield between those claiming to fight in the name of God and others who were allegedly standing against God's religion." Like the NASL's statements, Al-Sisi's words demarcated a frontier between the legitimate body of the nation and its external antagonist other. This frontier pitted "the people" against "the people" (Mogahed, 2013). The Anti-Coup Alliance and its supporters, according to Al-Sisi, were on the one side of this divide. The honorable Egyptian people whom he asked to take to the streets on July 26 , were on the other.

While it is arguable, if Al-Sisi's speech reflected a personal recognition of his role as the dominant player in the post-coup order, the Mandate Speech indeed became an indicator of popular support for the general. On the evening of the defense minister's speech, presidential spokesman Ahmed al-Muslimani confirmed the interim president's support for Al-Sisi's “war 
on terrorism," and welcomed Al-Sisi's call to protect the revolution and the state (Fahim \& Sheikh, 2018a). Within hours after Al-Sisi's speech, the armed forces declared a nationwide state of alert and deployed additional troops in all provinces. State television channels added the tagline didda al-irhab [against the Terrorism] as a banner to their news broadcasts. Soon all six of the major private satellite channels also adopted variations of the banner, reading "Egypt against terrorism," "together against terrorism" or "the people's word against extremism" (Bradley, 2014). Moreover, the Tamarod movement echoed Al-Sisi's call to the streets and declared its full support for the armed forces to confront the terrorism of the Muslim Brotherhood (see Saleh, 2013). The National Salvation Front toed the line and emphatically urged the government to disband the Anti-Coup sit-ins.

By contrast, the NASL perceived Al-Sisi's address as an announcement of another massacred and a prelude to a civil war (see RNN, 2013a). Furthermore, the different parties represented in the NASL seized on the general's speech as evidence that Egypt was returning to fascist military rule. On behalf of all players in the alliance, the Muslim Brotherhood released a statement on July 24 that likened Al-Sisi's speech to that of Bashar al-Assad on March 30 , 2011 (see Muslim Brotherhood, 2013b). In this much-anticipated speech before to the Syrian People's Assembly, the Syrian president had requested a similar mandate to confront plots to destroy the nation.

\section{Mandate Friday}

Walter Armbrust (2015, p. 105) has interpreted the protests on July 26, 2013, as the decisive moment of Al-Sisi's ascension to power. After Mandate Friday, as the protests responding to Al-Sisi's speech are commonly known, the general separated from his prior institutional function as a mere arbiter of social unrest and assumed a more political role. Hundreds of thousands of Egyptians had answered the general's call and demanded action against the Anti-Coup protest camps. Aside from the NASL, only the Nour Party and the April 6 Movement had boycotted the protests.

Mandate Friday thus effectively became a barometer for the Egyptians' willingness to support a crackdown on the Islamist demonstrations. Encouraged by the broad support, the prosecution brought charges of murder and conspiracy with the Palestinian Hamas against Mohammed Mursi that same day (Pioppi, 2013, n. 60). Moreover, the Ministry of Interior announced that the occupied squares would soon be cleared in an orderly and legal way. The following night, the police moved against the Rabaa al-Adawiya sit-in for the first time (Chayes, 2013). The offensive mirrored that at the Republican 
Guard barracks three weeks earlier: After barraging the surroundings of the Rabaa camp with teargas, the CSF advanced on Nasr street, the slip road to the Rabaa camp, with army units as a backup. The ensuing clashes in front of the Minassa [podium] memorial of former President Sadat lasted until the early next morning. They left over 100 people dead and many more injured.

The clashes on Nasr Street were the hitherto worst single mass killings in the republic's history. Many of the corpses, examined by journalists and human rights defenders in the surrounding morgues, exhibited head wounds from sniper fire and multiple bullet holes in their torsos which pointed to heavy machine gun use (EIPR, 2014, p. 57; Human Rights Watch, 2014, p. 124ff.). The figures released by Wiki Thawra confirm that security forces had stepped up their use of lethal violence: While the killed-injured ratio stood at an average of one killed versus 13 injured in the Republican Guard killings, this ratio moved to 1:7 during the clashes on Nasr Street. Uploaded videos confirm the uncontrolled use of live ammunition which Egyptian authorities deny up to the present day. ${ }^{20}$ By contrast, there is little evidence for the use of firearms by NASL demonstrators (see Human Rights Watch, 2014, p. 128f.). The observation that CSF and army units captured on film neither wore ballistic vests nor took cover from enemy fire suggests that protesters were mostly unarmed.

Against this background, the nightly operation on Nasr Street failed to achieve its intended effect. The excessive and disproportionate police violence not only nourished protesters' grievances and strengthened their affective commitments. It also granted legitimacy to demands for legal recognition of all mass killings. After the Republican Guard massacre, seeking justice for the victims of state repression, the release of detained protesters, and the impartial investigation of army and police crimes had become part of the campaign's demands. These demands became more central following the clashes on Nasr Street. They soon ranked equally to the calls for Mursi's reinstatement (see Figure 7, new elements shaded in grey).

On August 7, 2013, FJP General Secretary Mohamed Al-Beltagy announced on the Rabaa-podium that the sit-ins would no longer end with the return of the elected president to his office. Anti-Coup protesters would not demobilize until those responsible for shedding the martyrs' blood were tried in court and the judiciary had undergone a reform to safeguard against another counterrevolution ( $\mathrm{RNN}, 2013 \mathrm{c})$. According to Al-Beltagy and his allies in the NASL, a comprehensive transitional justice process would need to include not only investigations into the killing of protesters but also into 
Figure 7 Evolution of Anti-Coup demands in response to repression

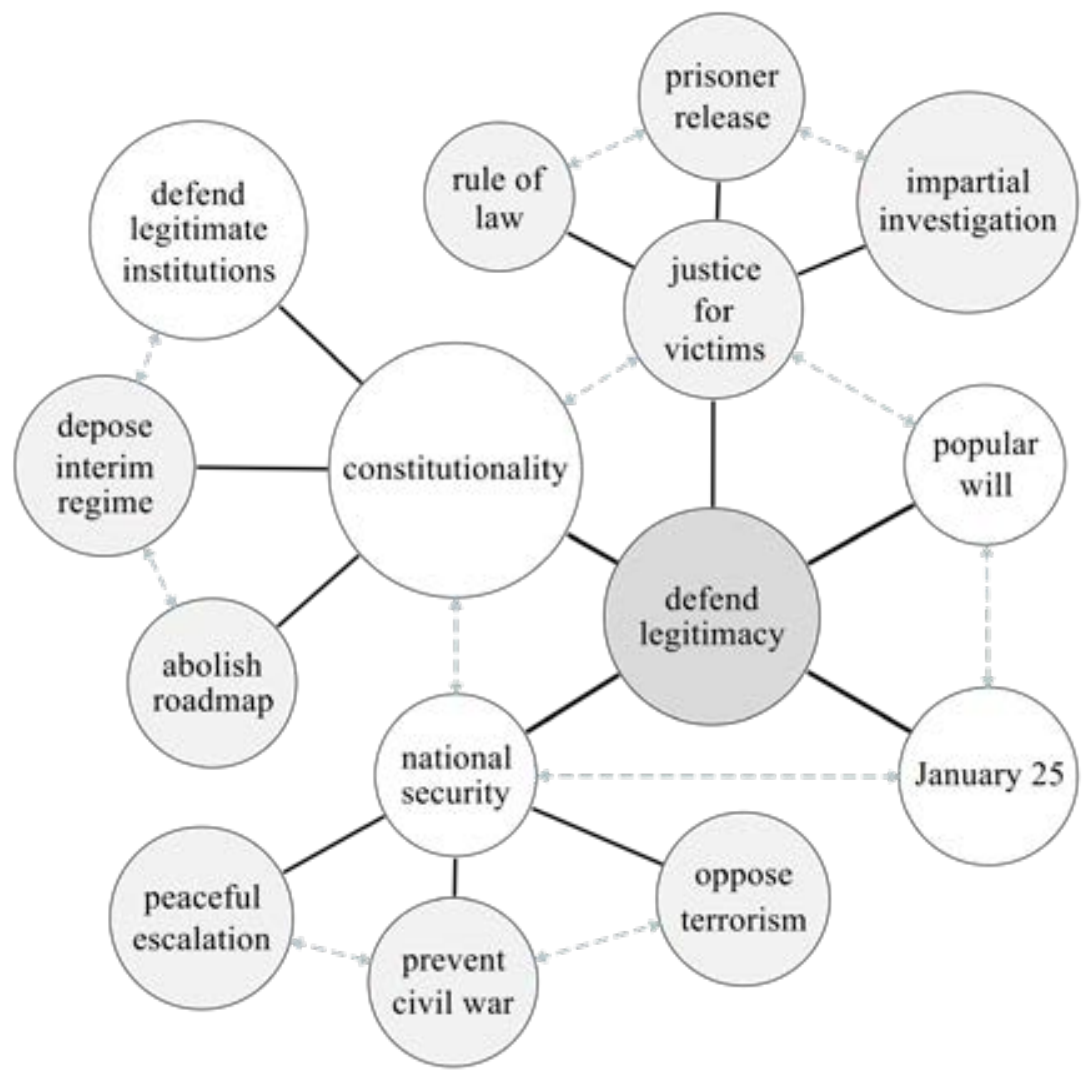

the fabrication of criminal charges and the censorship of Brotherhoodaffiliated media outlets (see NASL, 2013r, 2013s). The alliance additionally called on the International Criminal Court to prosecute Al-Sisi for crimes against humanity (Muslim Brotherhood, 2013b).

This turn towards the international community marked a shift from prior communications which had mostly framed foreign governments and international organizations as accomplices of the coup. It partly responded to the growing international criticism of the Egyptian security forces' conduct in Cairo. The NASL saw the notes of concern by the UN General Secretary and High Commissioner for Human Rights as opportunities to lobby their agenda in an international arena and parallelly to the domestic arenas where the dialogue processes with other political forces had come to a standstill.

On a domestic level, by contrast, Anti-Coup statements concentrated on evoking sympathies among the broader Egyptian public. The indiscriminate 
use of automatic weapons on Nasr Street allowed the NASL to liken the police operation to the infamous massacre of Coptic demonstrators by army units in front of the Maspero television building in October 2011 - an event that is firmly engrained in Egyptians' collective memory about military rule after 2011 (see M. Youssef et al., 2014). Like the Maspero killings, the alliance stressed, the Minassa massacre pointed to an evident collapse of the rule of law. According to the Anti-Coup Alliance, a "law of the jungle" had taken over the protest arena and was enforced by the "henchmen" of the military coup (NASL, 2013n).

At the same time, Anti-Coup representatives tried to reshape the image of their camps as incubators for terrorism through a PR offensive. A Rabaa tour with visits to the field hospital and the main stage aimed to counter the securitization of the protests by state media (Johanson, 2013). Launched by several young NASL supporters in early August, the daily tours with the motto "Heard enough, time to see!" meant to dispel rumors of extremism, kidnapping, and torture inside the camp. A promotional text, which was widely shared on social media, invited Egyptians and international observers to visit the sit-ins and verify their peacefulness themselves. ${ }^{21}$ But the PR offensive city failed to generate much resonance (Holmes, 2013). An official Rabaa sit-in tour bus (NASL, 2013t) fared no better.

\section{Competing Conceptions of Terror}

Furthermore, the NASL attempted to counter the regime's vilification at demonstration marches themselves by appropriating the terrorism label as a nodal signifier in its discourse. After the Minassa massacre, new protest chants directly referenced Al-Sisi's mandate speech and stressed the protesters' principled nonviolence. Slogans such as, "to those standing at the window, we are your brothers, not terrorists" (Nagi, 2013c), featured prominently in the Anti-Coup marches, alongside regular rhythmic references to silmiya [peacefulness]. Many protesters began to carry posters in Arabic and English - thus addressing both a domestic and international crowd - which rejected the terrorism label and highlighted the victimization of protesters by police brutality. The dissemination of such counter-narratives to the vilification by authorities turned into a central motivation for the protests.

21 The full statement is available at https://archive.is/wip/fonRi. It was followed shortly by a professionally edited promotion video which can be viewed at https://www.youtube.com/ watch?v=C2j6GopsL3s 
To subvert the securitization of its campaign, the NASL additionally gave further weight to its prior framing of repression as state terrorism. In several statements, it denounced Al-Sisi's talk about a war on terrorism as a cover for his own criminal conduct (e.g., NASL, 2013p). Visits by human rights organizations to the Anti-Coup protest sites would reveal that the coup forces were the ones who were practicing "terrorism, extermination, murder, threats, and intimidation of the oppressed" (NASL, 2013q). This state terrorism in disguise was replicating Mubarak's way of ruling, but it would not prevent the alliance from protesting - just as smear campaigns and police repression had not stopped the January 25 Revolution.

Some within the Anti-Coup Alliances advanced this narrative more zealously than others, such as FJP Secretary-General Mohamed AlBeltagy who was quoted as asking the crowds in Rabaa to "prepare for a second jihad" (ABC/AFP, 2013). In its official communication, however, the NASL was wary of any religious subtext and avoided framing its resistance as a jihad-like zero-sum game between believers and infidels (see Alimi, 2009, p. 226; Olesen, 2009, p. 9). The exception was a recurrent reference to the fifth surah of the Quran. According to the cited verse no. 32, whenever someone killed another human being, this was as if he had killed all mankind. Moreover, many Anti-Coup statements appealed to the security forces' conscience by quoting the Prophet Mohammed, according to whom there was no duty to obey any leader if this meant disobeying Allah.

Apart from such abstract appeals to its antagonist's moral emotions, the NASL notably curbed its efforts to persuade members of the armed forces to support its cause. Condemnations of the military became less differentiated after the Minassa massacre. According to the NASL, army units had partaken in the coup forces' "eradication policy" by supporting the police forces with gas bombs and providing cover for snipers (NASL, $2013 \mathrm{~m})$. The armed forces were given a final choice:

The question to the Supreme Council of the Armed Forces remains: is it looking for political solutions to the crisis of the homeland [...] or has it accepted the language of genocide, murder, kidnapping, fabrication of charges, and muffling of mouths practiced by some of the leaders of the armed forces as a solution for any crisis. (NASL, 20130)

The forces in the Anti-Coup Alliance also ran out of patience with other social players. After the mandate speech, the NASL reached out to third parties - including the Grand Imam of Al-Azhar Ahmad al-Tayyeb - in an 
Figure 8 Construction of antagonist other after Mandate Friday

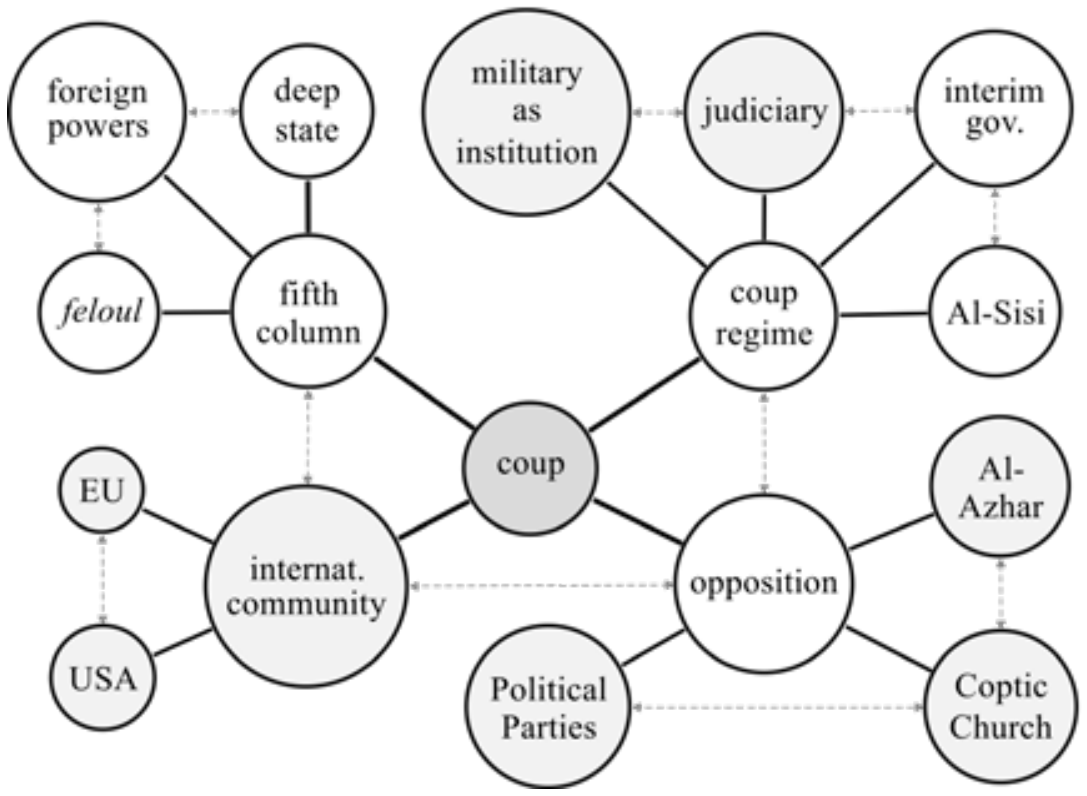

attempt to restart reconciliation efforts (see Muslim Brotherhood, 2013b). But considering many of these players' blessing of Al-Sisi's words and their justification of the ensuing violence as ugly but necessary efforts at curbing the growing instability, these discussions became increasingly obsolete. After the killings, the NASL asserted, it would not engage in any more talks with either of the parties who had lent their support to the interim government, because they were no longer "unbiased mediators but partners in the putschists' crime" (Muslim Brotherhood, 2013d). This included Sheikh Ahmed al-Tayyeb who, according to the NASL (2013c), had tolerated the presence of snipers on the premises of Al-Azhar University, as well as a range of foreign players who had remained silent over the mass violence (NASL, 2013q). Particularly the U.S. administration and the European Union had supposedly abetted the killing of unarmed civilians by recognizing and financing the post-coup regime.

With the list of enemies growing (see Figure 8, new elements shaded in grey), the odds of turning the Anti-Coup movement into a broader alliance dwindled, as did the chances for a peaceful mediation of the conflict. Accordingly, the NASL abandoned prior thoughts about reconciliation and turned toward a portrayal of the campaign as a fight of one against all. Henceforth, this narrative remained the dominant tenor of the Anti-Coup 
campaign and imbued the protesters with what Jasper (2018) has referred to as a "deontological pride" (p. 5). In a massive backlash, this feeling of moral superiority provided fresh impetus to the protest campaign. Protest rates increased continuously. By the middle of August, the two camps in Rabaa and Al-Nahda Square had developed into entire tent cities. These were replete with functioning internal infrastructure, constantly harboring an average of 85,000 protesters. ${ }^{22}$

\section{Setting Course for Violence}

Among those players who backed Al-Sisi's call for a war on terror, the Minassa clashes equally marked a point of no return. The clashes were still ongoing when Interior Minister Ibrahim declared that the units on Nasr Street were unarmed and had "never pointed a weapon towards the chest of a protester."23 Instead, he portrayed the clashes as fighting between demonstrators and residents of the Nasr City neighborhood. During the following days, the prevention of such clashes became a pretext for expanding the security forces' room for maneuver in preparation of a raid against the Anti-Coup camps. These preparations included the transferal of emergency powers to Prime Minister Hazem al-Beblawi and the authorization of civilian arrests by army forces. President Mansour also authorized the deployment of military infantry against the protest camps and, in a highly contentious move, restored the infamous anti-Islamist units of the State Security Service. A symbol of Mubarak's police oppression, these units had supposedly been dissolved in March 2011.

On July 29, 2013, the National Defense Council (NDC), Egypt's highest body on matters of domestic security, then announced that evidence was growing that the Anti-Coup sit-ins posed a threat to national security (Dakroury, 2013). Its statement no longer differentiated between most peaceful demonstrators and individual violent elements within the NASL. Instead, it collectivized the blame for the escalating street violence and placed it on the entire contentious alliance. On July 31, 2013, the cabinet followed

\footnotetext{
22 Participant counts based on satellite photographs of an average night at the sit-in suggest that between 71,000 and 100,000 protesters camped on Rabaa Square alone (see Human Rights Watch, 2014, n. 32). Other calculations suggest that the total occupied area housed around 300,000 protesters, with an additional 245,000 protesters on Al-Nahda Square (see S. Ismail, 2013). These variances can partly be explained by the fact that turnouts varied significantly between Friday and regular weekdays.

23 For a video of the press conference see https://www.youtube.com/watch?v=yblonfpcHıU.
} 
suit and empowered the Ministry of Interior to take steps against such threats to public security. A deployment plan was signed off by the NDC a few days later.

After a week of escalating rhetoric, on August 7, 2013, President Mansour declared that all mediation efforts had failed and a decision had been taken to clear the sit-ins after the end of Ramadan. ${ }^{24}$ This sealed a spiral of violence that culminated in the "worst mass unlawful killings in the country's modern history" (Human Rights Watch, 2013b). However, the security forces' indiscriminate and disproportionate application of force also provided the Anti-Coup Alliance with a new motive for continued resistance. It created myths and martyrs which began to figure strongly in the Anti-Coup resistance discourse as embodiments of the movement's righteousness and moral superiority. As the following chapter shows, it was the strong intertwining of these moral emotions with the principled commitment to peaceful resistance that explains the Anti-Coup Alliance's resilience in the face of unprecedented repression. At the same time, it prevented the protesters from turning to a more violent contentious repertoire - and thus from following in the footsteps of predecessor cases of Islamist coup-ousting in the region.

\section{References}

Abaza, M. (2014). Post January revolution Cairo: Urban wars and the reshaping of public space. Theory, Culture \& Society, 31(7-8), 163-183. https://doi.org/10.1177/0263276414549264

ABC/AFP. (2013, July 25). Egypt's military, Muslim Brotherhood call for protests. ABC News. https://www.abc.net.au/news/2013-07-25/egypts-defiant-muslim-brotherhood-leaderurges-27stand27-a/4844700

Abdel Ghaffar, A. (2013, August 7). Egypt's framing wars of June 3oth. OpenDemocracy. http:// www.opendemocracy.net/adel-abdel-ghafar/egypts-framing-wars-of-june-3oth

Abdelbaseer, M. (2016, January 25). Cairo's Rabaa massacre: Between a murderous army and urban failure. FA: Failed Architecture. https://www.failedarchitecture.com/ cairos-rabaa-massacre-between-a-murderous-army-and-urban-failure/

Abdelrahman, M. (2017). Policing neoliberalism in Egypt: The continuing rise of the 'securocratic' state. Third World Quarterly, $38(1), 185$-202. https://doi.org/10.1080/01436597.2015.1133246

Abedine, S., \& Abdelaziz, S. (2013, July 25). Pro-Morsy group calls for Egypt protests, warns of violence. CNN. https://edition.cnn.com/2013/o7/24/world/africa/egypt-unrest/index.html

24 Several international organizations and a range of prominent Egyptians from the liberal as well as the Islamist spectrum tried to avert the looming confrontation. Amongst others, the EU, the African Union, the US State Department, the former Brotherhood member Abdel Moneim Aboul-Futuh and the acting vice president and Nobel Peace Prize laureate Mohammed El-Baradei. 
Al-Awadi, H. (2013). Islamists in power: The case of the Muslim Brotherhood in Egypt. Contemporary Arab Affairs, 6(4), 539-551. https://doi.org/10.1080/17550912.2013.856079

Alimi, E. Y. (2009). Mobilizing under the gun: Theorizing political opportunity structure in a highly repressive setting. Mobilization, 14(2), 219-237. https://doi.org/10.17813/ maiq.14.2.u210745765568737

Alsharif, A., \& Saleh, Y. (2013, October 10). Special report: The real force behind Egypt's 'revolution'. Reuters. https://www.reuters.com/article/us-egypt-interior-specialreport/ special-report-the-real-force-behind-egypts-revolution-of-the-state-idUSBRE99908D20131010

Amar, P. (2011). Turning the gendered politics of the security state inside out? International Feminist Journal of Politics, 13(3), 299-328. https://doi.org/10.1080/14616742.2011.587364

Amar, P. (2013). The security archipelago: Human-security states, sexuality politics, and the end of neoliberalism. Duke University Press.

Amnesty International. (2013, July 10). Egypt:Damning evidence points to security forces' failures. https://www.amnesty.org/en/press-releases/2013/o7/egypt-damning-evidence-pointssecurity-forces-failures/

Armbrust, W. (2015). The iconic stage: Martyrologies and performance frames in the January $25^{\text {th }}$ revolution. In R. Abou-El-Fadl (Ed.), Revolutionary Egypt: Connecting domestic and international struggles (pp. 43-64). Routledge.

Bolliger, R., Elmenshawy, M., \& Weilandt, R. (2016). The military, the media and public perceptions in Egypt: Communication and civil-military relations (Egypt Civil-Military Relations Conference Paper Series No. 3). Geneva Centre for the Democratic Control of Armed Forces. https://www.dcaf.ch/sites/default/files/publications/documents/Egypt_Civil_Paper3_ENG. pdf

Bradley, M. (2014, May 29). Egyptian TV swayed public against Morsi, in favor of Sisi. Wall Street Journal. http://www.wsj.com/articles/egyptian-tv-swayed-public-against-morsi-in-favorof-sisi-1401330765

Buzan, B., Wæver, O., \& Wilde, J. de. (1998). Security: A new framework for analysis. Lynne Rienner Pub.

Chayes, S. (2013, August 1). The Egyptian Restoration. Carnegie Endowment for International Peace. http://carnegieendowment.org/2013/08/o1/egyptian-restoration/gh3o

Dakroury, N. (2013, July 29). National Defence Council closely monitoring Rabaa and Al-Nahda sit-ins. Daily News Egypt. https://www.masress.com/en/dailynews/207454

EIPR. (2014). The weeks of killing: State violence, communal violence and sectarian attacks in the summer of 2013. Egyptian Initiative for Personal Rights. https://eipr.org/sites/default/files/ reports/pdf/weeks_of_killing-en.pdf

El-Dabh, B. (2013, July 8). Sorrow and anger at Rabaa Al-Adaweya. Daily News Egypt. https:// dailynewsegypt.com/2013/07/08/sorrow-and-anger-at-rabaa-al-adaweya/

El-Issawi, F. (2014). The role of Egyptian media in the coup. In IE Med. Mediterranean Yearbook 2014 (pp. 299-304). http://www.iemed.org/observatori/arees-danalisi/arxius-adjunts/anuari/ anuari-2014/ElIssawi_egypt_media_military_coup_IEMed_yearbook_2014_EN.pdf

Escobales, R., Holpuch, A., \& Weaver, M. (2013, July 5). Egypt's 'day of rejection' - Friday 5 July as it happened. The Guardian. https://www.theguardian.com/world/middle-east-live/2013/ jul/o5/egypt-braced-day-of-rejection-live

Fahim, K., \& Sheikh, M. E. (2018, October 19). Egyptian general calls for mass protests. The New York Times. https://www.nytimes.com/2013/07/25/world/middleeast/egypt.html

Ghanem, T. (2016, May 30). O brother, what is prison? On Malek Adly. Mada Masr. http://www. madamasr.com/opinion/o-brother-what-prison-malek-adly

Gribbon, L., \& Hawas, S. (2012). Signs and signifiers: Visual translations of revolt. In S. Mehrez (Ed.), Translating Egypt's revolution: The language of Tahrir (pp. 103-142). Oxford University Press. 
Grimm, J. J., \& Harders, C. (2018). Unpacking the effects of repression: The evolution of Islamist repertoires of contention in Egypt after the fall of President Morsi. Social Movement Studies, $17(1), 1-18$. https://doi.org/10.1080/14742837.2017.1344547

Hafez, M. (2003). Why Muslims rebel: Repression and resistance in the Islamic world. Lynne Rienner Publishers.

Hanafi, A. (2015). Qamos Al-Thawra: A dictionary of the revolution. http://qamosalthawra.com/en

Holmes, A. A. (2013, August 16). Before the bloodletting: A tour of the Rabaa Sit-in. The Cairo Review of Global Affairs. https://www.thecairoreview.com/tahrir-forum/before-the-bloodletting-atour-of-the-rabaa-sit-in/

Human Rights Watch. (2013a, July 5). Egypt: Deadly clashes at Cairo University. https://www. hrw.org/news/2013/07/05/egypt-deadly-clashes-cairo-university

Human Rights Watch. (2013b, August 19). Egypt: Security forces used excessive lethal force. https:// www.hrw.org/news/2013/o8/19/egypt-security-forces-used-excessive-lethal-force

Human Rights Watch. (2014, August 12). All according to plan: The Rab'a massacre and mass killings of protesters in Egypt. https://www.hrw.org/report/2014/o8/12/all-according-plan/ raba-massacre-and-mass-killings-protesters-egypt

Imad, A. G. (2014). Islamists between revolution and the state: An epilogue. Contemporary Arab Affairs, 7(2), 283-298.

Ismail, S. (2013, July). Mathematics and Egyptians don't mix: June 30 protests figures. The Revolution Fails. https://therevolutionfails.tumblr.com/post/56565464162/mathematicsand-egyptians-dont-mix-june-3o

Jasper, J. M. (2018). The emotions of protest. The University of Chicago Press.

Jasper, J. M., Young, M. P., \& Zuern, E. (2020). Public characters: The politics of reputation and blame.

Johanson, M. (2013, August 7). 'Rabaa tours' seeks brave tourists for trips into Cairo's Pro-Morsi Protest Camp. International Business Times. https://www.ibtimes.com/rabaa-tours-seeksbrave-tourists-trips-cairos-pro-morsi-protest-camp-1374953

Ketchley, N. (2014). “The army and the people are one hand!” Fraternization and the 25th January Egyptian Revolution. Comparative Studies in Society and History, 56(1), 155-186. https://doi. org/10.1017/Soo10417513000650

Kingsley, P., \& Green, L. (2013, July 18). Killing in Cairo: The full story of the Republican Guards' club shootings. The Guardian. http://www.theguardian.com/world/interactive/2013/jul/18/ cairo-republican-guard-shooting-full-story

Liu, J. (2011, February 20). Roundabouts and revolutions: The "Arab street" begins and ends in a circle. https://www.vice.com/en_us/article/788d7e/roundabouts-and-revolutions-the-“arabstreet"-begins-and-ends-in-a-circle

McCurdy, P., Feigenbaum, A., \& Frenzel, F. (2016). Protest camps and repertoires of contention. Social Movement Studies, 15(1), 97-104. https://doi.org/10.1080/14742837.2015.1037263

Mogahed, D. (2013, July 25). Deep runs the divide [Carnegie Endowment for International Peace]. Sada. http://carnegieendowment.org/sada/index.cfm?fa=show\&article $=52493 \&$ solr_hilite $=$

Mohsen, A. A. (2013, July 9). The killing of Islamist protesters: State censorship or self-censorship? Mada Masr. https://madamasr.com/en/2013/o7/og/news/u/the-killing-of-islamist-protestersstate-censorship-or-self-censorship/

Mohsen, M. (2013, July 10). Arrest warrants for Badie and nine others for Republican Guard clashes. Daily News Egypt. /node/1542?language=en

Monier, E. I., \& Ranko, A. (2013). The fall of the Muslim Brotherhood: Implications for Egypt. Middle East Policy, 20(4), 111-123. https://doi.org/10.1111/mepo.12050

Mursi, M. (2013a, June 26). Address to the nation on the occasion of the anniversary of his inauguration [Arabic, on file]. 
Mursi, M. (2013b, July 2). Urgent statement by the presidency of the republic [Arabic, on file].

Muslim Brotherhood. (2013a, June 29). National Alliance in Support of Electoral Legitimacy's speech to the Egyptian people on the eve of 30 June. Ikhwanweb. http://www.ikhwanweb. com/article.php?id $=31062$

Muslim Brotherhood. (2013b, July 25). Statement by the Anti-Coup Alliance in response to Al-Sisi's speech. Ikhwanweb. https://archive.vn/wip/uVAHa

Muslim Brotherhood. (2013c, August 3). Anti-Coup Alliance statement condemns security forces attack on Friday 2 August. Ikhwanweb. http://www.ikhwanweb.com/article.php?id=31211

Muslim Brotherhood. (2013d, August 6). Anti-Coup Alliance statement affirms no invitation to dialogue received. Ikhwanweb. http://www.ikhwanweb.com/article.php?id=31233

Nagi, M. (2013a, July 15). No meetings between military and Muslim Brotherhood: FJP spokesperson. Daily News Egypt. http://www.dailynewsegypt.com/2013/07/15/ no-meetings-between-military-and-muslim-brotherhood-fjp-spokesperson/

Nagi, M. (2013b, July 26). Pro-Morsi march jovial at Al-Nahda Square. Daily News Egypt. https:// dailynewsegypt.com/2013/07/26/pro-morsi-march-jovial-at-al-nahda-square/

NASL. (2013a, July 2). The text of the statement of the National Alliance in response to the statement of the army. https://alaam25o.blogspot.de/2013/o7/blog-post.html

NASL. (2013b, July 3). Statement 4 [Arabic, on file].

NASL. (2013c, July 4). From the field command of the sit-ins to our brothers in the armed forces [Arabic, on file].

NASL. (2013d, July 4). Statement 6 [Arabic, on file].

NASL. (2013e, July 5). On the events of the Friday miliuniya [Arabic]. Facebook. https://archive. vn/wip/ZeiXt

NASL. (2013f, July 7). Statement 9 [Arabic, on file].

NASL. (2013g, July 7). To the Egyptian people [Arabic]. https://archive.vn/wip/XcvSh

NASL. (2013h, July 8). Statement 10 [Arabic]. https://archive.vn/wip/R39Gf

NASL. (2013i, July 11). Statement 12: Principles of the January 25 revolution [Arabic]. Facebook. https://archive.is/wip/lHSRE

NASL. (2013j, July 15). National Alliance in Support of Legitimacy statement condemns coup; calls for peaceful protests. Ikhwanweb. http://www.ikhwanweb.com/article.php?id=31144

NASL. (2013k, July 16). On the formation of the fake government [Arabic]. Facebook. https:// archive.vn/wip/jVhUC

NASL. (2013l, July 16). To the armed forces [Arabic]. Facebook. https://archive.vn/wip/7 $\mathrm{H}_{4} \mathrm{QE}$

NASL. (2013m, July 26). On the massacre of Rabaa al-Adawiya [Arabic]. Facebook. http://bit. $\mathrm{ly} / 2 \mathrm{PZfxD} 6$

NASL. (2013n, July 26). Statement 37 [Arabic]. Facebook. https://archive.vn/wip/MuACe

NASL. (20130, July 27). Regarding the efforts and initiatives put forward within the framework of constitutional legitimacy [Arabic]. Facebook. http://bit.ly/2Q Q1RaVi

NASL. (2013p, July 29). Statement 42: The National Alliance responded to the allegations of the National Defence Council [Arabic]. Facebook. https://archive.vn/bItCH

NASL. (2013q, August 1). Statement 47 [Arabic]. Facebook. http://bit.ly/2Q1Lv1o

NASL. (2013r, August 3). Anti-Coup Alliance statement on US delegation meeting on Saturday. Ikhwanweb. http://www.ikhwanweb.com/article.php?id=31215

NASL. (2013s, August 3). Statement 49: On the meeting with the US delegation [Arabic]. Facebook. https://archive.vn/wip/2iK 3 m

NASL. (2013t, August 6). Come join the Rabaa sit-in tour bus [Arabic]. Facebook. https://archive. vn/wip/rgDp3

Olesen, T. (2009). Social movement theory and radical Islamic activism. In Islamism as social movement (pp. 7-33). CIR Aarhus Universität. 
Osman, M. (2013). Baseera public opinion poll on Egyptians' living conditions and their expectations for the future. Baseera. http://baseera.com.eg/baseera/pdf_poll_file_en/Expectations\%20 for\%2othe\%2oFuture-en.pdf

Owen, P., \& McCarthy, T. (2013, July 8). 51 Morsi supporters killed in shooting at Republican Guard compound. The Guardian. http://www.theguardian.com/world/middle-east-live/2013/ jul/o8/egypt-34-killed-in-shooting-at-compound-where-morsi-is-being-held-live-coverage

Pearlman, W. (2018). Contingency and agency in a turning point event: March 18, 2011, in Daraa, Syria. In F. Volpi \& J. M. Jasper (Eds.), Microfoundations of the Arab uprisings: Mapping interactions between regimes and protesters (pp. 111-134). Amsterdam University Press.

Pioppi, D. (2013). Playing with fire: The Muslim Brotherhood and the Egyptian Leviathan. The International Spectator, 48(4), 51-68. https://doi.org/10.108o/03932729.2013.84768o

Pratt, N. (2015). After the 25 January Revolution: Democracy or authoritarianism in Egypt? In R. Abou-el-Fadl (Ed.), Revolutionary Egypt: Connecting domestic and international struggles. Routledge.

Rahin, A. (2013, July 17). Al-Arian told Al-Hayat: The army contacted us and al-Sisi refused to negotiate with Qandil [Arabic]. Al-Hayat. https://bit.ly/2HhısLD

Richter, C. (2017). Mobilize, justify, accuse: The Egyptian Muslim Brotherhood and changing media practices. In S. Foellmer, M. Lünenborg, \& C. Raetzsch (Eds.), Media practices, social movements, and performativity: Transdisciplinary approaches (pp. 100-113). Routledge.

Rivera Celestino, M. (2012). Violence breeds violence: How violent crime affects repression in democratic regimes [Paper presented at the Workshop 'Advancing the Scientific Study of Conflict and Cooperation: Alternative Perspectives from the UK and Japan', 20-21 March 2012]. http://privatewww.essex.ac.uk/ ksg/esrcjsps/Rivera.pdf

RNN. (2013a, July 24). National Alliance: Al-Sisi speech is a call for civil war [Arabic]. Rassd News Network. https://archive.vn/wip/hmZx9

RNN. (2013b, August 7). Al-Beltagy states three demands after the return of Morsi [Arabic]. Rassd News Network. https://archive.vn/wip/NodXo

Saleh, Y. (2013, July 24). Egypt's Tamarud youth group backs army call for protests. Reuters. https:// www.reuters.com/article/us-egypt-protests-youth-idUSBRE96NoHV20130724

Sayigh, Y. (2012). Above the state: The officers'republic in Egypt. Carnegie Endowment for International Peace. http://carnegieendowment.org/2012/08/o1/above-state-officers-republic-in-egypt/ $\mathrm{d}_{4} \mathrm{l} 2$

Schielke, S. (2017). There will be blood: Expectation and ethics of violence during Egypt's stormy season. Middle East Critique, 26(3), 205-220. https://doi.org/10.108o/19436149.2017.1336023

Schwedler, J. (2016). Taking time seriously: Temporality and the Arab uprisings. Project on Middle East Political Science. https://pomeps.org/2016/06/10/taking-time-seriously-temporalityand-the-arab-uprisings/

Schwedler, J. (2018). Routines and ruptures in anti-Israeli protests in Jordan. In F. Volpi \& J. M. Jasper (Eds.), Microfoundations of the Arab uprisings: Mapping interactions between regimes and protesters (pp. 67-88). Amsterdam University Press.

Springborg, R. (2018). Egypt. Polity.

Underhill, H. (2016). Translating and diaspora politics: Narrating the struggle at 'home' and 'abroad'. In M. Baker (Ed.), Translating dissent: Voices from and with the Egyptian Revolution (pp. 45-59). Routledge, Taylor \& Francis Group.

Waever, O. (1995). Securitization and desecuritization. In R. D. Lipschutz (Ed.), On security (pp. 46-86). Columbia University Press.

Wahba, D. (2020). A thug, a revolutionary or both? Negotiating masculinity in post-revolutionary Egypt. Middle East - Topics \& Arguments, 14, 56-65. https://doi.org/10.17192/meta.2020.14.8265

Weizman, E., Fisher, B., \& Moafi, S. (2015). The roundabout revolutions. Sternberg Press. 
Wessel, S. (2016). Grey-scales: Negotiating the civil state in post-revolutionary Egypt (CARPO Study: The Dawla Madaniyya Series No. 3). CARPO. https://carpo-bonn.org/ wp-content/uploads/2016/12/CARPO_Study_03_2016_Wessel.pdf?fbclid=IwAR1xw91dRRjp9wRIW_oxoPdhQK $7 \mathrm{Y}_{2}$ GoMo-id_V7MoslqGV5zRjKbWifoFw

Wessel, S. (2018). The 'third hand' in Egypt. Middle East Law and Governance, 10(3), 341-374. https://doi.org/10.1163/18763375-01003006

Yates, L. (2015). Rethinking prefiguration: Alternatives, micropolitics and goals in social movements. Social Movement Studies, 14(1), 1-21. https://doi.org/10.1080/14742837.2013.870883

Youssef, M., Arafa, H., \& Kumar, A. (2014). Arab revolutions: Breaking fear: Mediating discourse of democratic uprising in Egypt: Militarized language and the "battles" of Abbasiyya and Maspero. International Journal of Communication, 8(1), 871-889. 